\title{
Hydrogeology and groundwater evaluation of a shallow coastal aquifer, southern Akwa Ibom State (Nigeria)
}

\author{
Aniekan Edet ${ }^{1}$
}

Received: 14 May 2015/Accepted: 17 May 2016/Published online: 3 June 2016

(c) The Author(s) 2016. This article is published with open access at Springerlink.com

\begin{abstract}
The rapid expansion of economic activities in coastal parts of Nigeria has triggered an uncoordinated development of groundwater leading to stress on the resource. Hence a study was conducted to assess the hydrogeological characteristics of the shallow coastal aquifer of southern Akwa Ibom State, Nigeria. Emphasis was on the hydraulic characteristics, quality with respect to domestic and irrigation purposes and influence of seawater. The study result revealed that the aquifer consist of intercalations of clayey sand and sand. The aquifer is characterized by high hydraulic conductivity and transmissivity values. The groundwater flow direction is southwards with higher groundwater depletion in the dry season. Groundwater samples from hand dug wells and boreholes were evaluated based on World Health Organization standard and some indices, respectively, for drinking and irrigation uses. The groundwaters are fit for drinking and domestic uses. However, more than $70 \%$ of the $\mathrm{pH}$ values are not within the allowable limits of between 6.5 and 9.2 for drinking and domestic use. Therefore, it is recommended that neutralizing filter containing calcite or ground limestone should be applied to raise the $\mathrm{pH}$ of the groundwater. Of the 10 parameters used to assess the water for irrigation use, only sodium adsorption ratio (SAR), magnesium hazard $(\mathrm{MH})$ and magnesium ratio indicated the excellent quality of these waters. $\mathrm{Na}^{+}-\mathrm{K}^{+}-\mathrm{HCO}_{3}{ }^{-}$constitute the dominant water type. Total dissolved solids and ratios of $\mathrm{Na}^{+} / \mathrm{Cl}^{-}, \mathrm{Mg}^{2+} / \mathrm{Cl}^{-}$, and $\mathrm{Ca}^{2+} / \mathrm{SO}_{4}{ }^{2-}$ and saltwater
\end{abstract}

Aniekan Edet

aniekanedet@yahoo.com; aniekanedet25@gmail.com

1 Department of Geology, University of Calabar, Calabar, Nigeria mixing index (SMI) suggest some level of seawater intrusion in the area.

Keywords Aquifer parameters - Groundwater quality · Coastal aquifer - Seawater intrusion · Nigeria

\section{Introduction}

Groundwater is the major source of water for most uses in Nigeria in particular and the globe in general (Bear 1979). Of the $37 \mathrm{Mkm} 3$ of estimated freshwater available on earth, about $22 \%$ exists as groundwater, which constitutes about $97 \%$ of all freshwater available for human use (Foster 1998). It is estimated that about one-third of the world's population use groundwater for drinking (Nickson et al. 2005), domestic, irrigation and industrial purposes. The availability and quality of groundwater resources have been affected by activities and projects associated with developments in the coastal areas over the last decades. Coastal aquifers are generally fragile and in most region of the world, these aquifers are depleted due to over exploitation of groundwater (Chidambaram et al. 2008). During high tide, seawater finds its way through creeks and creeklets, thereby intruding the shallow freshwater aquifers. This results in the salinization of the coastal freshwater aquifers. Groundwater in the area exists in a shallow coastal aquifer which constitutes major source of water in southern Akwa Ibom State (AKS) for domestic and industrial purposes and most of the rural areas for drinking. Groundwater in shallow aquifers can be replenished more frequently and rapidly relative to deep coastal aquifers in the northern part of AKS (not part of the study). However, these aquifers are sensitive to human activities mainly from maritime, oil and gas, steel, agricultural, industrial and

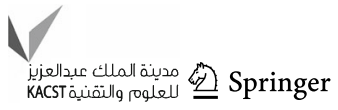


municipal activities, etc., because of shallow water level couple with runoff and proximity to rural population centres. Therefore groundwater contamination is always a possibility in shallow coastal aquifers in the vicinity of major development areas.

The present study evaluates hydraulic characteristics, groundwater chemistry and groundwater quality. The water quality variations from different sources and its suitability for drinking and irrigation purposes were also assessed.

\section{Study area}

The study area lies in southern parts of Akwa Ibom State (Fig. 1), which is one of the very active coastal districts in southern parts of Nigeria covering an estimated area of $1095 \mathrm{~km}^{2}$. The area lies between latitudes $4^{\circ} 30.268-4^{\circ} 38.981$ North and longitudes $7^{\circ} 32.490-8^{\circ} 18.610$ East. The area is drained mainly by Imo River, Kwa Iboe River and Cross River together with their tributaries (Fig. 1). The area is mostly flat lying sandy coastal area. The main landforms are mangrove swamps and floodplains with recent alluvial accumulations, beach ridges and mangrove mudflats (Petters 1989). The minimum and maximum temperature in the study area ranges from 26 to $28{ }^{\circ} \mathrm{C}$. The area experiences two seasons: wet season (April-October) and dry season (November-March).
The average annual rainfall is about $3000 \mathrm{~mm}$ and the area experiences humid tropical climate.

\section{Geological setting}

The area of investigation belongs to southern Nigerian Coastal Plain Sand as shown on the Geological Survey Map series of Nigeria [Sheet 79 (Umuahia), Sheet 82 (Calabar)]on scale 1:250,000 (GSN 1962). The work of Petters $(1982,1989)$, showed that the area belongs partly to the coastal plain sands, beach ridge complex and alluvium of Quaternary Period (Table 1). The area consists of freshwater dryland, freshwater swamp, coastal brackish water swamp, and beach ridge complex. The alluvial sands are fine to very coarse grained (Fig. 2a). The floodplain muds and clay are light grey. The freshwater swamp belt is landward of brackish water swamp zone and gradational to it. The brackish water zone is landward of beach zone and the mangrove swamp belt. The materials here are silt to fine grained sand that is subangular to subrounded and very well rounded. The floodplains and interdistributary areas comprise dark to light grey carbonaceous mud and clay (Fig. 2b). Alluvial deposits occur along banks of major rivers. The sands are greyish to light brown and range in size from fine to coarse grained (Petters 1989).

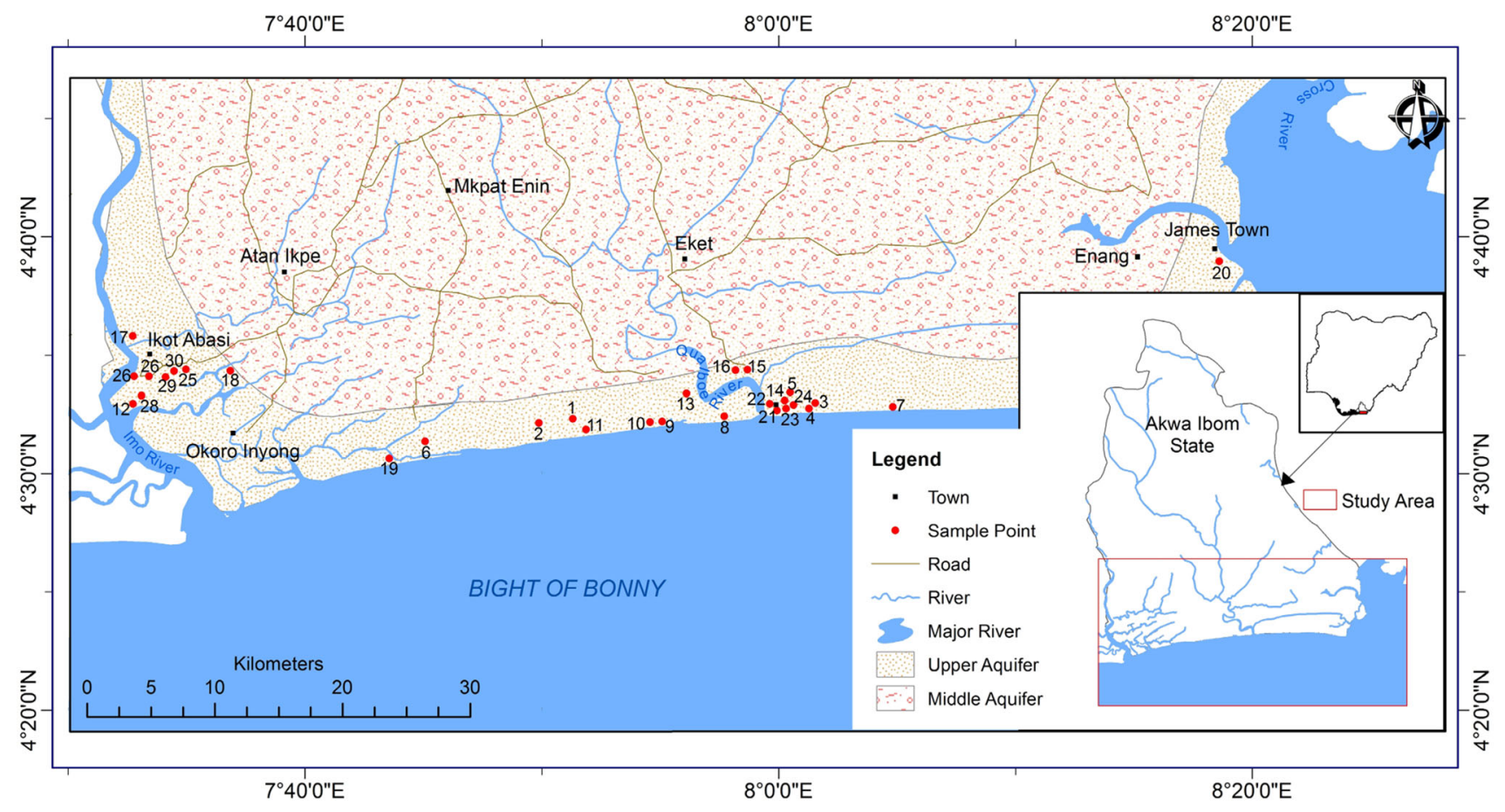

Fig. 1 Location map of study area, southern Akwa Ibom State 
Table 1 Stratigraphic relation of the units in southern Akwa Ibom State

\begin{tabular}{llll}
\hline Period & Epoch & Formation & Aquifer \\
\hline Quaternary & Recent & Alluvium & Upper sand \\
& & Beach ridges & \\
& Pliocene-Pleistocene & Benin formation or & \\
& & Coastal plain sand & \\
\hline
\end{tabular}

Modified from Petters (1989) and Esu et al. (1999)

\section{Hydrogeologic framework}

Groundwater in Akwa Ibom occurs in three major systems (Esu et al. 1999): (1) the upper aquifer system; (2) the middle aquifer system and (3) the lower aquifer system. The present study is concern with the upper aquifer system. The upper aquifer consists of clayey sand to sand with varying proportions of gravel (Fig. 3) that reaches $30 \mathrm{~m}$ in thickness (Esu et al. 1999) and fully saturated. The aquifer is recharged by percolation of rainfall and direct infiltration of river water. Discharge from the aquifer takes place through withdrawals from wells, boreholes, ponds, percolation into the underlying middle and lower aquifer systems and evaporation in places where the water table is close to the ground surface.

Hydraulic conductivity $(K)$ estimated from grain size distribution curve using Hazen method (Fetters 2001) ranges between 12 and $19 \mathrm{~m} /$ day. Pumping test data yield hydraulic conductivity values of between 4 and $11 \mathrm{~m} /$ day (Tahal 1980). The hydraulic gradient in the area varies between $5.89 \times 10^{-5}$ and $1.42 \times 10^{-4}$, with an overall average of $1.02 \times 10^{-4}$. Transmissivity range from 147.5 to $620 \mathrm{~m}^{2} /$ day (average $314.5 \mathrm{~m} /$ day) and are in the range of very high transmissivity value (Krásńy 1993). Depth to water table ranges from 0.4 to $15 \mathrm{~m}$ below the ground surface and gradually approaches the ground surface in the lower reaches.
Fig. 2 a Typical floodplains mud and $\mathbf{b}$ typical alluvial sands
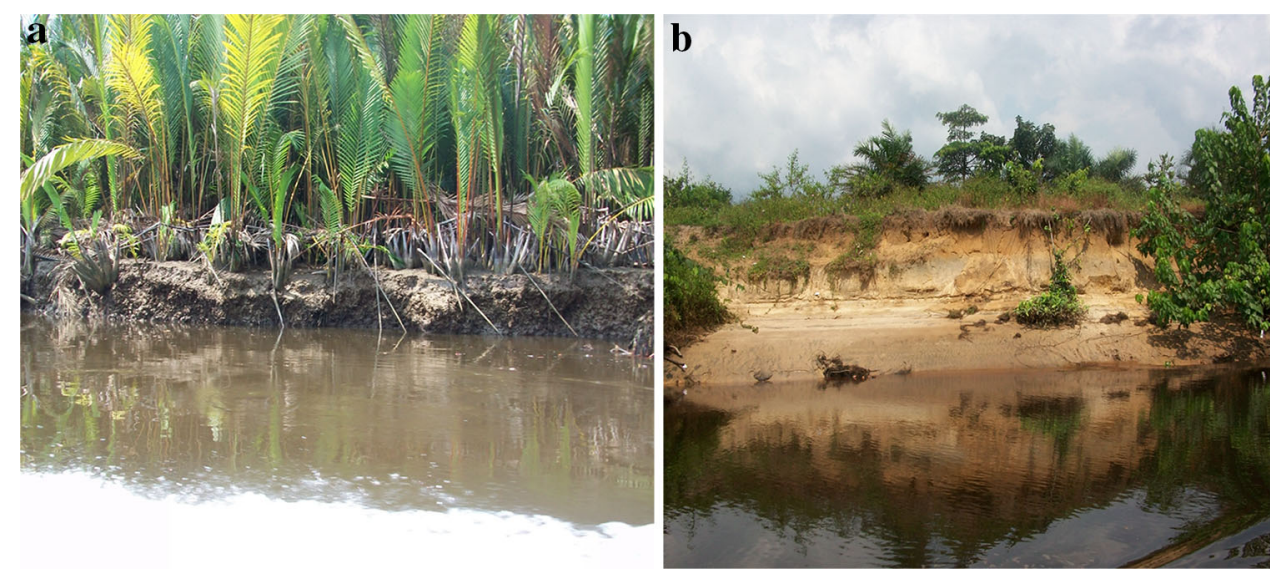

Fig. 3 Hydro-lithologic cross section across the study area

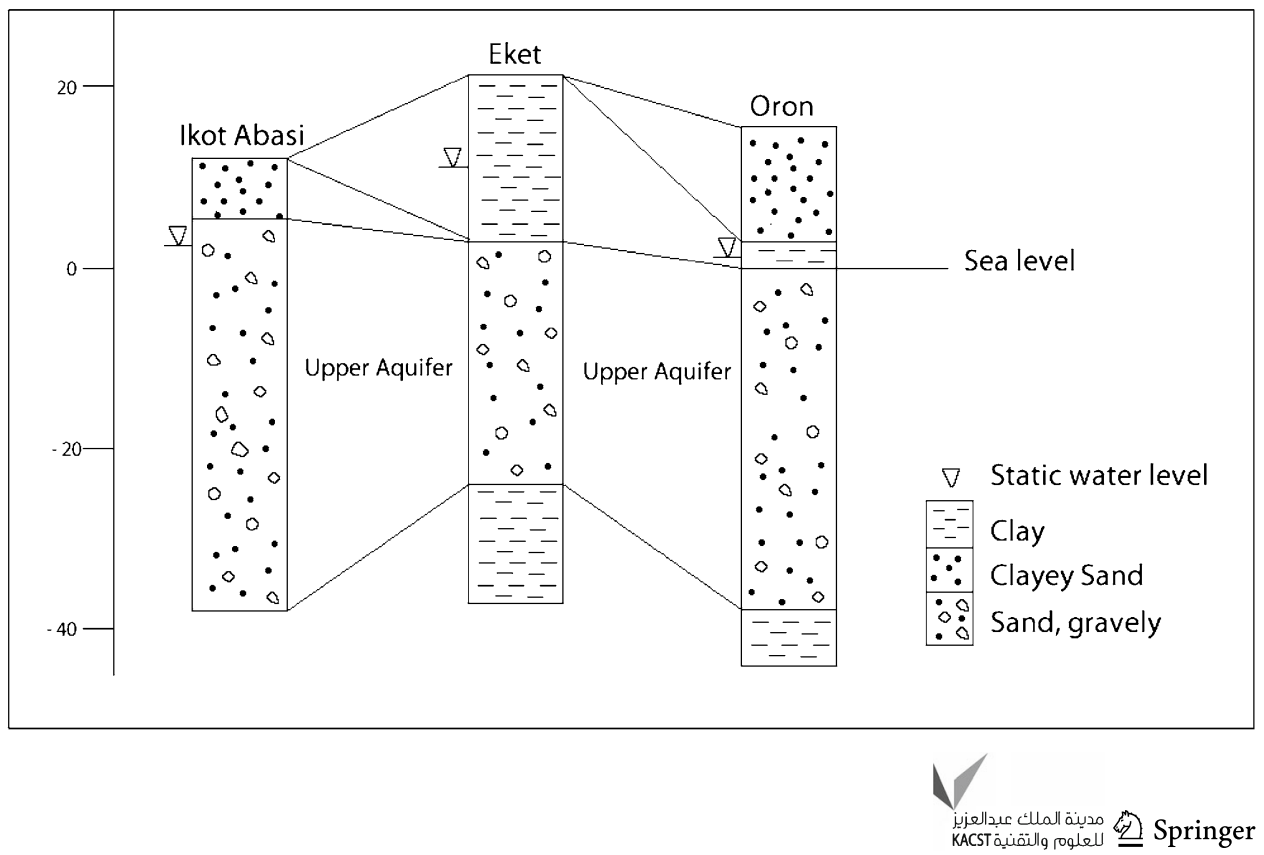


The present study is concerned with the upper aquifer system. In this aquifer, water is abstracted through hand dug wells $(<10 \mathrm{~m}$ deep) and shallow boreholes $(<60 \mathrm{~m}$ deep). Hence groundwater chemistry is discussed in the light of upper parts $(<10 \mathrm{~m})$ of the upper aquifer based on groundwater samples from hand dug wells and lower parts based on groundwater samples obtained from shallow boreholes terminated within the lower sections $(>10 \mathrm{~m}$ sample depth $<60 \mathrm{~m}$ ) of the upper aquifer.

\section{Groundwater flow patterns and fluctuations}

General groundwater levels within the aquifer appear to follow the topography. Figure 4 is a contour map of the measured groundwater levels within the upper sand aquifer. The measurements show that the groundwater flows from topographic high areas towards topographic lower areas into the Atlantic Ocean. Groundwater fluctuations monitored during wet and dry seasons indicted higher levels with respect to the ground surface compared to lower levels in the dry season (Table 2). This is attributed to low withdrawals and high recharge and vice versa in the wet and dry seasons, respectively.

\section{Recharge estimation}

Recharge to shallow coastal aquifer usually occurs from rainfall and infiltration from rivers. The amount of recharge is dependent on the frequency of rainfall. Tahal (1980) estimates the recharge rate in the coastal plain sands of the entire Akwa Ibom State is about $36 \%$ of precipitation. Annual rainfall in the study area is about $3000 \mathrm{~mm}$ and average runoff of $1495 \mathrm{~mm} / \mathrm{a}$ (Tahal 1980). Thus $50 \%$ of rainfall volume flows as runoff in the area. The chloride mass balance $(\mathrm{CMB})$ method was used to estimate recharge for the present study area, southern parts of Akwa Ibom State. The CMB method provides a direct estimation procedure of the groundwater recharge. It is based on the assumption that chloride concentrations in rainfall and recharge are in steady-state balance, i.e., input is equal to output without chloride storage change during a time period (Al-Shaibani 2008). The CMB has been seen to yield values of groundwater recharge comparable to those obtained by physically based methods (Wood 1996).

The CMB method requires only knowledge of annual precipitation, chloride concentration in precipitation and chloride concentration in groundwater. The fundamental equation of CMB method is given as (Wood and Sandford 1995):

$Q=R \times \mathrm{Cl}_{\mathrm{rw}} / \mathrm{Cl}_{\mathrm{gw}}$,

where $Q=$ recharge $(L / T), R=$ annual rainfall $(L / T)$, $\mathrm{Cl}_{\mathrm{rw}}=$ average chloride concentration in rainfall $\left(\mathrm{M} / \mathrm{L}^{-3}\right)$,
$\mathrm{Cl}_{\mathrm{gw}}=$ average chloride concentration in groundwater $(\mathrm{M} /$ $\left.\mathrm{L}^{-3}\right), M=$ mass unit, $L=$ length unit and $T=$ time unit.

The concentration of chloride in precipitation of a coastal area, around Amasomma (not in study area, latitude $4^{\circ} 58^{\prime} 9 \mathrm{~N}$ longitude $6^{\circ} 6^{\prime} 35 \mathrm{E}$ ) is $0.47 \mathrm{mg} / \mathrm{l}$. Average chloride concentration in groundwater from the aquifer through borehole is $33.05 \mathrm{mg} / \mathrm{l}(n=20)$. From CMB equation above, the study area has a recharge of $42 \mathrm{~mm}$ or $1.42 \%$ of annual precipitation.

\section{Methods of study}

Groundwater samples were collected from 19 hand dug wells (Figs. 2 and 5) representing the upper layer of the Upper Aquifer and 11 boreholes representing the lower layer of the Upper Aquifer from various locations, which are used for drinking, domestic and irrigation purposes in 2011. However, since extensive work on groundwater quality was done in the inland areas (Edet 1993; Edet and Okereke 2001; Owolabi and Obot 1998), the present study was constrained towards the coastal areas to accommodate the influence of open ocean and estuaries. The water samples were collected in a high-density polyethylene bottles with 11 capacity. At the time of sampling, the bottles were rinsed three times with the water to be sampled. Prior to this, the bottles were washed and rinsed with deionized water.

The temperature, electrical conductivity (EC)/total dissolved solids (TDS), $\mathrm{pH} / \mathrm{Eh}$ and dissolved oxygen (DO) were measured in the field using portable Hanna water quality meters. Sodium $\left(\mathrm{Na}^{+}\right)$and potassium $\left(\mathrm{K}^{+}\right)$were measured using flame photometer. Calcium $\left(\mathrm{Ca}^{2+}\right)$ and magnesium $\left(\mathrm{Mg}^{2+}\right)$ were determined trimetrically using standard EDTA chloride $\left(\mathrm{Cl}^{-}\right)$, sulphate $\left(\mathrm{SO}_{4}{ }^{2-}\right)$, phosphate $\left(\mathrm{PO}_{4}{ }^{2-}\right)$ and nitrate $\left(\mathrm{NO}_{3}{ }^{-}\right)$were determined by $\mathrm{UV}-$ visible spectrophotometer ion chromatography Dionex 2000i with $\mathrm{Na}_{2} \mathrm{CO}_{3} / \mathrm{NaHCO}_{3}$ eluent. The concentration of bicarbonate $\left(\mathrm{HCO}_{3}{ }^{-}\right)$was determined by titration with hydrochloric acid at the Institute of Oceanography, University of Calabar (Nigeria) Laboratory shortly after sampling. The water quality assessment was based on a comparison with the maximum admissible value of WHO (1993, 2004) for drinking purposes. Total hardness (TH) was based on the scale of Sawyer et al. (2003). All the procedures were based on international standards documented in APHA (1995.

The suitability of the water for irrigation was assessed by means of hardness (Todd 1980; Sawyer et al. 2003), electrical conductivity (Todd 1980; Saleh et al. 1999), sodium adsorption ratio, SAR (Richards 1954), percent sodium, \%Na (Todd 1980) and magnesium hazard (MH), RSC (Ragunath (1987), permeability index, PI (Doneen 


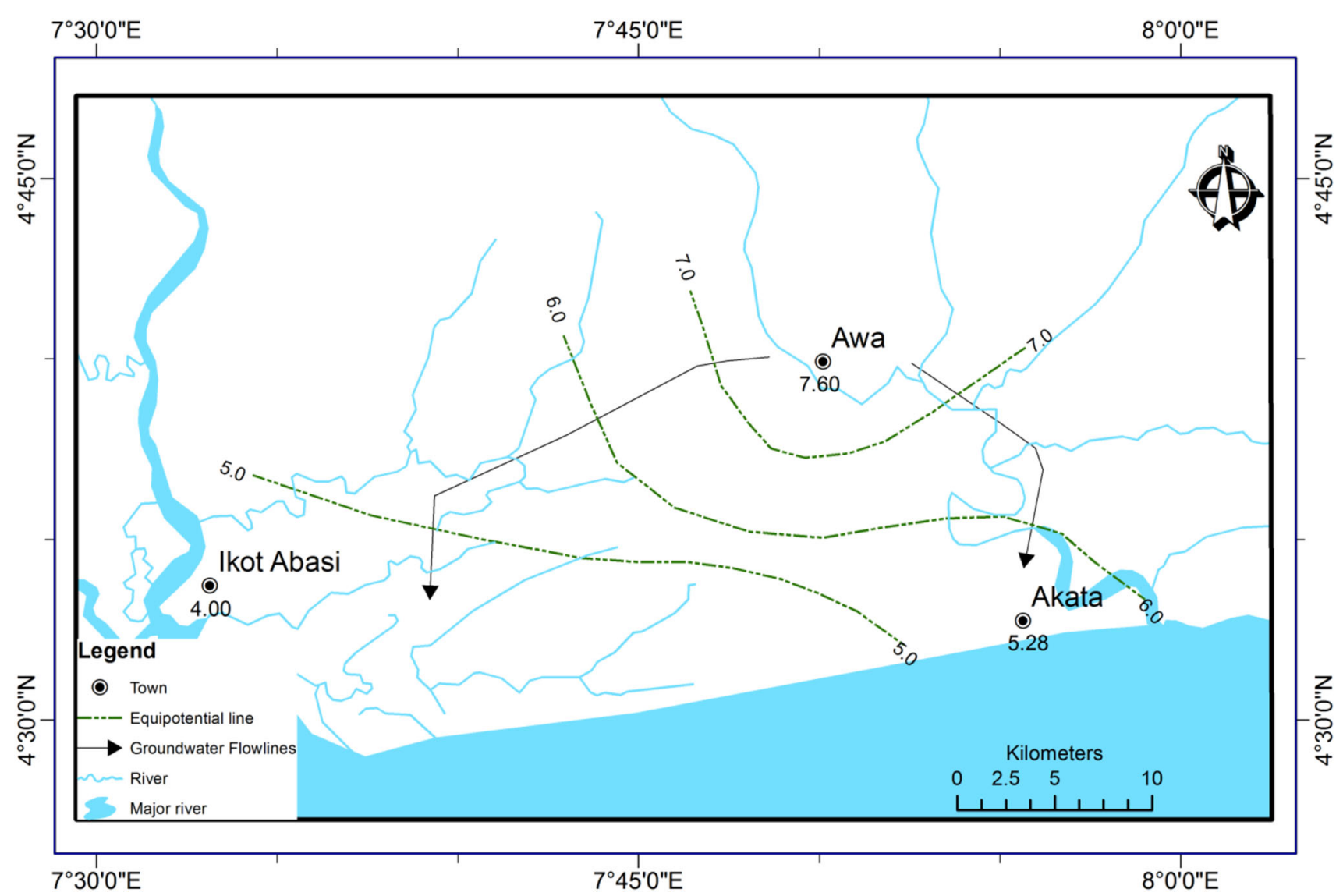

Fig. 4 Groundwater contour map within the study area

Table 2 Fluctuation in groundwater level between wet and dry seasons

\begin{tabular}{llll}
\hline Location $^{\mathrm{a}}$ & \multicolumn{2}{l}{ SWLwrtgs } & \\
\cline { 2 - 4 } & WS & DS & ASWL \\
\hline Ikot Abasi & 2.00 & 2.15 & 0.15 \\
Akata & 1.24 & 2.20 & 0.96 \\
Okoroette & 0.92 & 1.29 & 0.37 \\
Ibeno & 0.45 & 0.65 & 0.20
\end{tabular}

See Fig. 1

SWLwrtgs Static water level (SWL) with respect to ground surface $W S$ wet season, $D S$ dry season, $\triangle S W L$ change in SWL

1964), Kelly's ratio (Kelly 1940), magnesium hazard (Ravikumar et al. 2011), magnesium ratio, chloride and sulphate (Sagnak 1991; Bauder et al. 2004; Hopkins et al. 2007).

Total hardness $(\mathrm{TH})$ was calculated using the formula given by Sawyer et al. (2003):

$\mathrm{TH}\left(\right.$ as $\left.\mathrm{CaCO}_{3}\right) \mathrm{mg} / 1=\left(\mathrm{Ca}^{2+}+\mathrm{Mg}^{2+}\right) \times 50$

The SAR was estimated using Eq. 3 (Richards 1954):
$\mathrm{SAR}=\mathrm{Na} /[\sqrt{ }(\mathrm{Ca}+\mathrm{Mg}) / 2]$

The sodium percentage $(\mathrm{Na} \%)$ was calculated using Eq. 4 (Todd 1980):

$\% \mathrm{Na}=\left[\left(\mathrm{Na}^{+}+\mathrm{K}^{+}\right) /\left(\mathrm{Ca}^{2+}+\mathrm{Mg}^{2+}+\mathrm{Na}^{+}+\mathrm{K}^{+}\right)\right] \times 100$

The magnesium hazard ( $\mathrm{MH})$, calculated according to Eq. 5 (Ragunath 1987):

$\mathrm{MH}=\mathrm{Mg}^{2+} /\left(\mathrm{Ca}^{2+}+\mathrm{Mg}^{2+}\right)$

Water with high concentration of bicarbonate has the tendency of calcium and magnesium to precipitate as carbonate. To qualify this effect, Eaton (1950) developed the residual sodium carbonate (RSC), which is calculated as Ragunath (1987):

$\mathrm{RSC}=\left(\mathrm{HCO}_{3}^{-}+\mathrm{CO}_{3}^{2-}\right)-\left(\mathrm{Ca}^{2+}+\mathrm{Mg}^{2+}\right)$

Permeability index (PI) developed by Doneen (1964) is also used as a criterion to assess the quality of water for irrigation. The PI was calculated using Eq. 7:

$\mathrm{PI}=\left[\left(\mathrm{Na}^{+}+\sqrt{ } \mathrm{HCO}_{3}\right) / \mathrm{Ca}^{2+}+\mathrm{Mg}^{2+}+\mathrm{Na}^{+}\right] \times 100$ 


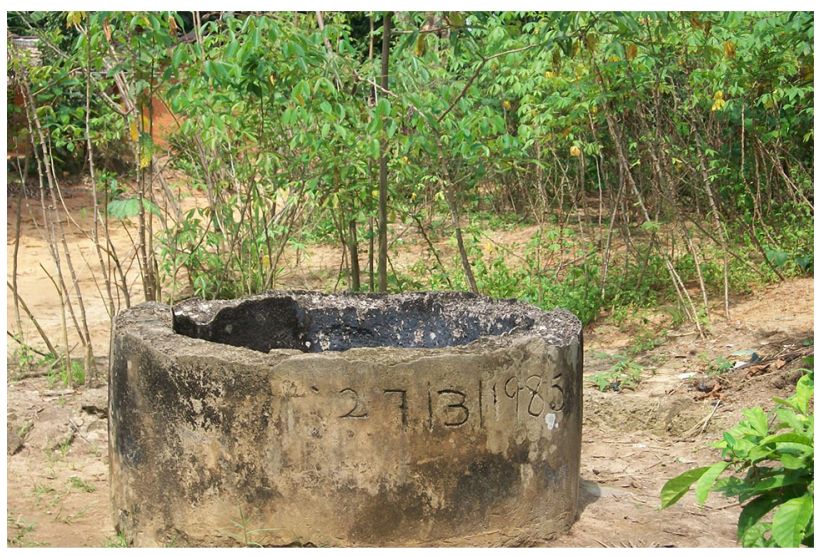

Fig. 5 Typical hand dug well (AK 12)

Sodium measured with respect to $\mathrm{Ca}^{2+}$ and $\mathrm{Mg}^{2+}$ is used to calculate Kelly's index, KI (Kelly 1940; Paliwal 1967). A KI of more than one indicates an excess level of sodium in water. Hence KI values less than one are suitable for irrigation, while the KI values with a ratio of more than one are unsuitable.

Generally, $\mathrm{Ca}^{2+}$ and $\mathrm{Mg}^{2+}$ maintain a state of equilibrium in most waters. $\mathrm{Ca}^{2+}$ and $\mathrm{Mg}^{2+}$ behave differently in soil system and $\mathrm{Mg}^{2+}$ destroys soil structure. In addition, high content of $\mathrm{Mg}^{2+}$ in soil is due to the presence of $\mathrm{Na}^{+}$ in soils. In equilibrium state, more high content of $\mathrm{Mg}^{2+}$ in water will adversely affect the soil quality by rendering it alkaline resulting in decrease crop yield (Ravikumar et al. 2011). Magnesium hazard (MH) more than $50 \%$ would adversely affect the crop yield as soil becomes more alkaline. Thus magnesium hazard (MH) is computed as

$\mathrm{MH}=\left[\left(\mathrm{Mg}^{2+}\right) /\left(\mathrm{Ca}^{2+}+\mathrm{Mg}^{2+}\right)\right] \times 100$

The magnesium ratio is based on the residual $\mathrm{Mg} / \mathrm{Ca}$ ratio, the groundwater samples can be classified as suitable, moderate or unsuitable for irrigation.

All concentrations in Eqs. (3) to (8) are expressed in meq/l.

\section{Results and discussion}

\section{Overview of groundwater chemistry for the area}

The results of the detailed and basic statistics of field measurements and chemical analyses for both hand dug well and shallow borehole water samples are summarized in Table 3. The ground water samples had temperatures during sampling varying between 25.2 and $35.1{ }^{\circ} \mathrm{C}$, reflecting average annual temperature of the study area. The $\mathrm{pH}$ of the groundwater ranged between 3.3 and 7.3, with an average of 5.75 , indicating acidic nature due to dissolved vegetative matter. The redox potential values were in the ranged $30-168 \mathrm{mV}$ indicating an oxidized environment. The electrical conductivity of groundwater in the area ranged between 35 and $1560 \mu \mathrm{S} / \mathrm{cm}$ with an average of $342.10 \mu \mathrm{S} / \mathrm{cm}$. The average TDS was $178.00 \mathrm{mg} / \mathrm{l}$, indicating freshwater (TDS $<1000 \mathrm{mg} / \mathrm{l}$ ). The dissolved oxygen varied between 1.00 and $12.00 \mathrm{mg} / \mathrm{l}$ with an average $4.29 \mathrm{mg} / \mathrm{l}$. The data showed that 17 out 30 groundwater samples considered, had DO values below $5.00 \mathrm{mg} / \mathrm{l}$, the minimum value required for drinking water. Low DO may be attributed to poor waste management in the area from indiscriminating waste disposal.

The dominant cation is $\mathrm{Na}^{+}$with an average concentration of $21.10 \mathrm{mg} / \mathrm{l}$. This is followed by $\mathrm{Ca}^{2+}, \mathrm{Mg}^{2+}$ and $\mathrm{K}^{+}$with average concentrations of $10.5,6.19$ and $3.78 \mathrm{mg} /$ 1 , respectively. The major anion is $\mathrm{HCO}_{3}{ }^{-}$with an average of $54.53 \mathrm{mg} / \mathrm{l}$, followed by $\mathrm{Cl}^{-}, \mathrm{NO}_{3}{ }^{-}$and $\mathrm{SO}_{4}{ }^{2-}$ with average concentrations of $29.78,10.07$ and $3.78 \mathrm{mg} / \mathrm{l}$, respectively. Despite the fact that the study area is close to the sea, the concentrations of TDS, $\mathrm{Na}^{+}$and $\mathrm{Cl}^{-}$, were low on the average (Table 3).

\section{Hand dug well (upper layer of the aquifer) water chemistry}

Details of the physicochemical parameters for groundwater samples obtained from hand dug wells are presented in Table 3. In respect of water from hand dug wells, the $\mathrm{pH}$ of water sample ranged from 3.30 to 6.80 with an average of 5.42. In general, $\mathrm{pH}$ of the shallow groundwater samples was found to be acidic in nature and not within the permissible limit suggested by WHO $(1993,2004)$. Only two well water samples from locations AK 14 and AK 19 had $\mathrm{pH}$ values within the permissible limit. The electrical conductivity (EC) values varied from 63.0 to $1561 \mu \mathrm{S} / \mathrm{cm}$ with an average of $362 \mu \mathrm{S} / \mathrm{cm}$. Saxena et al. (2004) and Mondal et al. (2009) classified water on the basis of EC into three categories: freshwater $(<1500 \mu \mathrm{S} / \mathrm{cm})$, brackish water $(1500-3000 \mu \mathrm{S} / \mathrm{cm})$ and saline water $(>3000 \mu \mathrm{S} /$ $\mathrm{cm})$. Based on this classification, all the samples fall within the freshwater class. Only one sample from location AK 12 with $\mathrm{EC}$ of $1561 \mu \mathrm{S} / \mathrm{cm}$ is brackish water. The total dissolved solids (TDS) of water varied from 41 to $780 \mathrm{mg} / \mathrm{l}$ with an average value of $189.21 \mathrm{mg} / \mathrm{l}$. These TDS values are below the maximum allowable limit (MAL) TDS guideline value of $1500 \mathrm{mg} / \mathrm{l}$ prescribed by WHO (1993).

The concentration of calcium ranged from 0.1 to 26 with an average of $8.82 \mathrm{mg} / \mathrm{l}$. Magnesium values in the shallow groundwater samples ranged between 0.1 and $18 \mathrm{mg} / \mathrm{l}$. The average value of $5.16 \mathrm{mg} / \mathrm{l}$ was recorded for magnesium. The concentrations of calcium and magnesium were below the MAL prescribed by WHO $(1993,2004)$. The concentration of potassium ranged from 0.4 to $13.00 \mathrm{mg} / \mathrm{l}$ with average value of $4.43 \mathrm{mg} / \mathrm{l}$. Sodium concentration ranged 


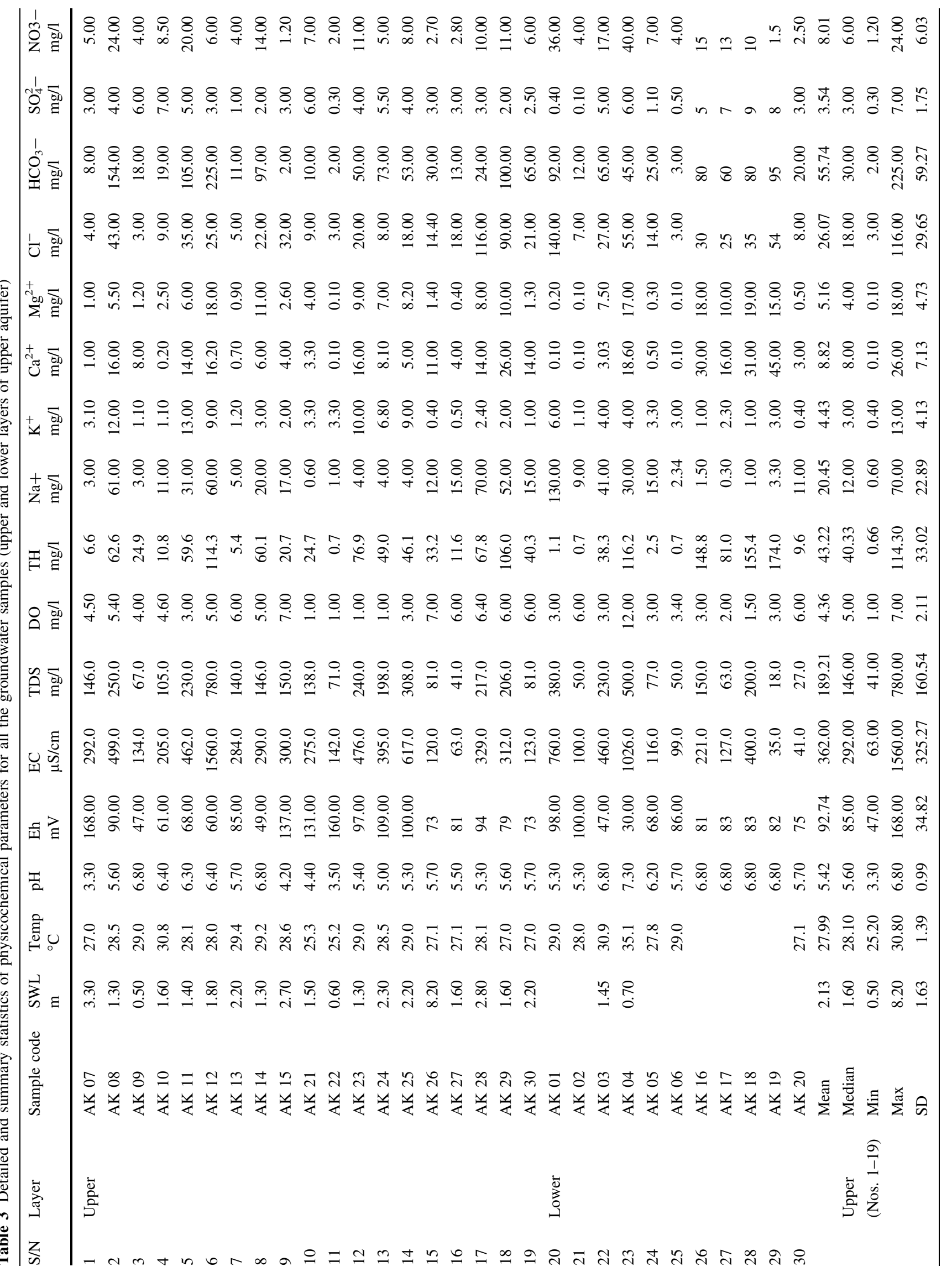


between 0.60 and $120 \mathrm{mg} / \mathrm{l}$. The average value was $20.45 \mathrm{mg} / \mathrm{l}$. All the shallow groundwater samples did not exceed the MAL (WHO 2004) limit for sodium (200 mg/l) and potassium $(12 \mathrm{mg} / \mathrm{l})$.

Bicarbonate values were recorded within the range of $2.0-225.0 \mathrm{mg} / \mathrm{l}$ with mean value of $55.74 \mathrm{mg} / \mathrm{l}$. According to WHO (2004) limit, all the shallow groundwater samples were found to be within the permissible limit of $500 \mathrm{mg} / \mathrm{l}$ with respect to bicarbonate. Chloride values varied from 3.00 to $116 \mathrm{mg} / \mathrm{l}$ for with mean value of $26.07 \mathrm{mg} / \mathrm{l}$. According to WHO, the MAL of chloride in groundwater is $600 \mathrm{mg} / \mathrm{l}$. Increased concentration of $\mathrm{Cl}(10-100 \mathrm{mmol} /$ 1) in freshwater aquifer is an indicator of seawater in a coastal area (Chandrasekhar et al. 2014). However, Appelo and Postma (1993) and Raju and Shukla (2011) suggested that high concentrations of chloride may result from pollution by domestic sewage, wastes and leaching of salt residue from soil. Sulphate values ranged from 1.2 to $24.0 \mathrm{mg} / \mathrm{l}$. Sulphate in water is through reduction, precipitation, solution and concentration as they traverse through sedimentary rocks such as gypsum and anhydrite. Nitrate varied between 0.3 and $7.0 \mathrm{mg} / \mathrm{l}$ with an average of $8.01 \mathrm{mg} / \mathrm{l}$. These values are within the WHO (1993) maximum admissible value of $45 \mathrm{mg} / \mathrm{l}$.

The cationic concentrations indicates that $26 \%$ of the shallow groundwater samples are $\mathrm{Na}^{+}>\mathrm{Ca}^{2+}>-$ $\mathrm{Mg}^{2+}>\mathrm{K}^{+}$, while $\mathrm{Mg}^{2+}>\mathrm{Ca}^{2+}>\mathrm{K}^{+}>\mathrm{Na}^{+}$and $\mathrm{Na}^{+}>\mathrm{Mg}^{2+}>\mathrm{Ca}^{2+}>\mathrm{K}^{+}$each constituted $16 \%$. Others were generally below $15 \%$ (Table 4 ). Based on the anionic concentration, the 19 shallow groundwater samples belong mainly to $\mathrm{HCO}_{3}{ }^{-}>\mathrm{Cl}^{-}>\mathrm{SO}_{4}{ }^{2-}$ and $\mathrm{Cl}^{-}>-$ $\mathrm{HCO}_{3}{ }^{-}>\mathrm{SO}_{4}{ }^{2-}$ (Table 5). Based on the ionic concentration, sodium bicarbonate is the dominant hydrochemical facies. Considering the average values, the concentrations of Eh, EC/TDS, DO, $\mathrm{K}^{+}$and $\mathrm{HCO}_{3}{ }^{-}$were higher in the hand dug wells compared to the borehole water samples.

\section{Borehole (lower layer of the aquifer) water chemistry}

Details of the physicochemical parameters for groundwater samples obtained from boreholes are presented in Table 3. The $\mathrm{pH}$ values of the deep groundwater samples ranged from 5.30 to 7.30 with average values of 6.32 , indicating acidic nature of the samples. The low values are attributed to humic acid from decay of vegetative materials and swampy nature of the sample locations (Fig. 2a). The EC ranged from 35.0 to $1026.0 \mu \mathrm{S} / \mathrm{cm}$. The average $\mathrm{EC}$ value was $307.73 \mu \mathrm{S} / \mathrm{cm}$. TDS values ranged between 18.0 and $500 \mathrm{mg} / \mathrm{l}$ with an average value of $158.64 \mathrm{mg} / \mathrm{l}$. The concentrations of the cations including sodium $(0.3-130.0 \mathrm{mg} /$ 1), potassium $(0.4-6.0 \mathrm{mg} / \mathrm{l})$, calcium $(0.10-60 \mathrm{mg} / \mathrm{l})$ and magnesium $(0.10-36.0 \mathrm{mg} / \mathrm{l})$ were all within the WHO 
Table 4 Allowable limits of drinking water based on WHO (1993, 2004)

\begin{tabular}{|c|c|c|c|c|c|c|}
\hline \multirow[t]{2}{*}{ Water quality parameter } & \multirow[t]{2}{*}{ Unit } & \multirow[t]{2}{*}{ WHO maximum allowable limit (MAL) } & \multicolumn{2}{|c|}{ No of samples exceeding MAL } & \multicolumn{2}{|c|}{ Percent exceeding MAL } \\
\hline & & & Upper aquifer & Lower aquifer & Upper aquifer & Lower aquifer \\
\hline $\mathrm{pH}$ & & $6.5-9.2$ & 17 & 5 & 90 & 46 \\
\hline Eh & $\mathrm{mV}$ & & & & & \\
\hline EC & $\mu \mathrm{S} / \mathrm{cm}$ & 1500 & 1 & & 5 & \\
\hline TDS & $\mathrm{mg} / \mathrm{l}$ & 1000 & & & & \\
\hline DO & $\mathrm{mg} / \mathrm{l}$ & $5 \min$ & 10 & 8 & 53 & 73 \\
\hline $\mathrm{TH}$ & $\mathrm{mg} / \mathrm{l}$ & 500 & & & & \\
\hline $\mathrm{Na}^{+}$ & $\mathrm{mg} / \mathrm{l}$ & 200 & & & & \\
\hline $\mathrm{K}^{+}$ & $\mathrm{mg} / \mathrm{l}$ & 12 & 1 & & & \\
\hline $\mathrm{Ca}^{2+}$ & $\mathrm{mg} / \mathrm{l}$ & 200 & & & & \\
\hline $\mathrm{Mg}^{2+}$ & $\mathrm{mg} / \mathrm{l}$ & 150 & & & & \\
\hline $\mathrm{Cl}^{-}$ & $\mathrm{mg} / \mathrm{l}$ & 250 & & & & \\
\hline $\mathrm{HCO}_{3}-$ & $\mathrm{mg} / \mathrm{l}$ & 600 & & & & \\
\hline $\mathrm{SO}_{4}^{2-}$ & $\mathrm{mg} / \mathrm{l}$ & 250 & & & & \\
\hline $\mathrm{NO}_{\underline{3}^{-}}$ & $\mathrm{mg} / \mathrm{l}$ & 50 & & & & \\
\hline
\end{tabular}

Table 5 Relative proportion of ions in the different water

\begin{tabular}{|c|c|c|c|c|c|}
\hline \multirow[t]{2}{*}{ Ions } & \multirow[t]{2}{*}{ Facies type } & \multicolumn{2}{|c|}{ Upper layer } & \multicolumn{2}{|c|}{ Lower layer } \\
\hline & & No. & $\%$ & No. & $\%$ \\
\hline \multirow[t]{11}{*}{ Cations } & $\mathrm{Mg}>\mathrm{Ca}>\mathrm{K}>\mathrm{Na}$ & 3 & 16 & 1 & 9 \\
\hline & $\mathrm{K}>\mathrm{Na}>\mathrm{Mg}>\mathrm{Ca}$ & 1 & 5 & & \\
\hline & $\mathrm{Ca}>\mathrm{Mg}>\mathrm{K}>\mathrm{Na}$ & 1 & 5 & & \\
\hline & $\mathrm{Na}>\mathrm{Mg}>\mathrm{K}>\mathrm{Ca}$ & 2 & 11 & & \\
\hline & $\mathrm{Na}>\mathrm{Ca}>\mathrm{Mg}>\mathrm{K}$ & 5 & 26 & 1 & 9 \\
\hline & $\mathrm{Ca}>\mathrm{Na}>\mathrm{Mg}>\mathrm{K}$ & 3 & 16 & & \\
\hline & $\mathrm{Na}>\mathrm{Mg}>\mathrm{Ca}>\mathrm{K}$ & 3 & 16 & 1 & 9 \\
\hline & $\mathrm{Mg}>\mathrm{Na}>\mathrm{Ca}>\mathrm{K}$ & 1 & 5 & 1 & 9 \\
\hline & $\mathrm{Na}>\mathrm{K} \mathrm{Mg}>\mathrm{Ca}$ & & & 4 & 36 \\
\hline & $\mathrm{Mg}>\mathrm{Ca}>\mathrm{Na}>\mathrm{K}$ & & & 1 & 9 \\
\hline & $\mathrm{Ca}>\mathrm{Mg}>\mathrm{Na}>\mathrm{K}$ & & & 2 & 18 \\
\hline \multirow[t]{3}{*}{ Anions } & $\mathrm{Cl}>\mathrm{HCO}_{3}>\mathrm{SO}_{4}$ & 7 & 37 & 6 & 55 \\
\hline & $\mathrm{HCO}_{3}>\mathrm{Cl}>\mathrm{SO}_{4}$ & 9 & 47 & 5 & 45 \\
\hline & $\mathrm{Cl}>\mathrm{SO}_{4}>\mathrm{HCO}_{3}$ & 3 & 16 & & \\
\hline
\end{tabular}

(1993, 2004) maximum admissible limits. For these groundwater samples, bicarbonate ranged between 3.0 and $95.0 \mathrm{mg} / \mathrm{l}$ with mean value of $52.45 \mathrm{mg} / \mathrm{l}$. According to WHO (2004) limit, all the shallow groundwater samples were found to be within the permissible limit of $500 \mathrm{mg} / \mathrm{l}$ with respect to bicarbonate. Chloride values varied from 3.00 to $140 \mathrm{mg} / \mathrm{l}$ for with mean value of $36.18 \mathrm{mg} / \mathrm{l}$. These values are below the WHO, the MAL of chloride in groundwater is $600 \mathrm{mg} / \mathrm{l}$. Sulphate values ranged from 0.10 to $9.0 \mathrm{mg} / \mathrm{l}$ with a mean of $4.10 \mathrm{mg} / \mathrm{l}$. Nitrate varied between 1.5 and $40.0 \mathrm{mg} / \mathrm{l}$ with an average of $13.64 \mathrm{mg} / \mathrm{l}$. These values are within the WHO (1993) maximum admissible value of $45 \mathrm{mg} / \mathrm{l}$.

Sodium is the major cation, which accounted for $48 \%$ of total cations. Magnesium is the second most abundant cation making up $23 \%$. Calcium makes up $22 \%$, while with only $7 \%$ potassium constitutes the least cation. For this aquiferous layer, the cation sequences are 
$\mathrm{Na}^{+}>\mathrm{K}^{+}>\mathrm{Mg}^{2+}>\mathrm{Ca}^{2+}$ and $\mathrm{Ca}^{2+}>\mathrm{Mg}^{2+}>-$ $\mathrm{Na}^{+}>\mathrm{K}^{+}$. Anionic concentration indicates that $55 \%$ of the groundwater samples are in sequence $\mathrm{Cl}^{-}>-$ $\mathrm{HCO}_{3}{ }^{-}>\mathrm{SO}_{4}{ }^{2-}$ while for the remaining $45 \%$, the sequence is $\mathrm{HCO}_{3}{ }^{-}>\mathrm{Cl}^{-}>\mathrm{SO}_{4}{ }^{2-}$

On the average, sodium and chloride are the dominant ions in deep groundwater samples. The average concentration of chloride accounts for about $46 \%$ of total anions. Chloride accounted for $45 \%$, while sulphate accounted for $9 \%$. Considering the average values, the concentrations of temp, $\mathrm{pH}, \mathrm{TH}, \mathrm{Na}^{+}, \mathrm{Ca}^{2+}, \mathrm{Mg}^{2+}, \mathrm{Cl}^{-}, \mathrm{SO}_{4}{ }^{2-}$ and $\mathrm{NO}_{3}{ }^{-}$ were higher in the borehole samples compared to the hand dug well samples.

\section{Multivariate statistical analyses}

\section{Correlation matrix}

Table 6 shows the results of correlation analysis of major ions. The correlation illustrates that EC/TDS shows positive correlation with $\mathrm{Na}^{+}, \mathrm{K}^{+}, \mathrm{Mg}^{2+}$ and $\mathrm{HCO}_{3}{ }^{-}$indicating that these ions are derived from same source. The strong correlation between EC/TDS, $\mathrm{Na}^{+}$and $\mathrm{HCO}_{3}{ }^{-}$ indicates such ions are derived from weathering of silicate minerals. The weak correlation between $\mathrm{Ca}^{2+}$ and $\mathrm{SO}_{4}{ }^{2-}$ indicates that gypsum is not the source of $\mathrm{Ca}^{2+}$. The correlation between $\mathrm{HCO}_{3}{ }^{-}, \mathrm{Ca}^{2+}$ and $\mathrm{Mg}^{2+}$ suggest carbonate dissolution. The other correlation pairs, $\mathrm{Na}^{+}-\mathrm{Mg}^{2+}$, $\mathrm{Na}^{+}-\mathrm{Cl}^{-}, \mathrm{Na}^{+}-\mathrm{SO}_{4}{ }^{2-}, \mathrm{Mg}^{2+}-\mathrm{HCO}_{3}{ }^{-}$and $\mathrm{Mg}^{2+}-\mathrm{SO}_{4}{ }^{2-}$ represent various processes operating in the area.

\section{Factor analysis}

Factor analysis is a multivariate statistical method that yields the relationship between measured chemical variables by showing multivariate patterns that may help to classify the original data. The geological interpretation of factors yields insight into the main process, which may govern the distribution of hydrochemical variables (Davis and Dewiest 2006; Bahar and Reza 2010). Factor analysis identifies several hydrochemical factors, but the interpretation of these factors is very subjective (Matalas and Reiher 1967). The result of the R-mode factor analysis indicated four factors which explained $76.90 \%$ of total data variance. The individual variances are $42.95,14.62,12.51$ and $6.82 \%$ for factors 1,2 , 3 and 4 (Table 7). From the Table 7, the variables EC, TDS, $\mathrm{TH}, \mathrm{Na}^{+}, \mathrm{K}^{+}, \mathrm{Mg}^{2+}$ and $\mathrm{HCO}_{3}{ }^{-}$have high positive loadings on factor 1. Temperature, $\mathrm{pH}, \mathrm{SO}_{4}{ }^{2-}$ and $\mathrm{NO}_{3}{ }^{-}$has high positive loading with Eh having high negative loading on factor 2. Factor 3 has high positive loadings on $\mathrm{Na}^{+}, \mathrm{Ca}^{2+}$ and $\mathrm{Cl}^{-}$, while factor 4 has high positive loadings for SWL, $\mathrm{K}^{+}$and high negative loading for DO. The presence of EC, TDS, $\mathrm{Na}^{+} \mathrm{K}^{+}, \mathrm{Mg}^{2+}$ and $\mathrm{HCO}_{3}{ }^{-}$in factor 1 indicates seawater influence and silicate weathering. Factor 2 is a $\mathrm{pH}$ factor due mainly to contributions from humic acid, poor waste management and pollution in from atmospheric sources especially, for nitrate (Jeong 2001). Factor 3 is due to sea water influence, while factor 4 has to do with decrease in oxygen due to poor waste management especially, where human waste are either buried in shallow pits or abandoned in the surface.

Table 6 Correlation matrix for shallow and deep groundwater parameters

\begin{tabular}{|c|c|c|c|c|c|c|c|c|c|c|c|c|c|c|c|c|}
\hline & SWL & Temp & $\mathrm{pH}$ & Eh & $\mathrm{EC}$ & TDS & DO & $\mathrm{TH}$ & $\mathrm{Na}^{+}$ & $\mathrm{K}^{+}$ & $\mathrm{Ca}^{2+}$ & $\mathrm{Mg}^{2+}$ & $\mathrm{Cl}^{-}$ & $\mathrm{HCO}_{3}^{-}$ & $\mathrm{SO}_{4}{ }^{2-}$ & $\mathrm{NO}_{3}{ }^{-}$ \\
\hline SWL & 1.00 & & & & & & & & & & & & & & & \\
\hline Temp & -0.23 & 1.00 & & & & & & & & & & & & & & \\
\hline $\mathrm{pH}$ & -0.19 & 0.68 & 1.00 & & & & & & & & & & & & & \\
\hline Eh & 0.13 & -0.63 & -0.99 & 1.00 & & & & & & & & & & & & \\
\hline EC & -0.20 & 0.41 & 0.34 & -0.30 & 1.00 & & & & & & & & & & & \\
\hline TDS & -0.17 & 0.38 & 0.34 & -0.30 & 1.00 & 1.00 & & & & & & & & & & \\
\hline DO & 0.21 & 0.52 & 0.39 & -0.43 & 0.21 & 0.23 & 1.00 & & & & & & & & & \\
\hline $\mathrm{TH}$ & -0.16 & 0.37 & 0.49 & -0.49 & 0.73 & 0.76 & 0.33 & 1.00 & & & & & & & & \\
\hline $\mathrm{Na}^{+}$ & -0.07 & 0.15 & 0.34 & -0.36 & 0.46 & 0.52 & 0.37 & 0.65 & 1.00 & & & & & & & \\
\hline $\mathrm{K}^{+}$ & -0.26 & 0.07 & 0.07 & 0.00 & 0.54 & 0.52 & -0.35 & 0.44 & 0.27 & 1.00 & & & & & & \\
\hline $\mathrm{Ca}^{2+}$ & -0.02 & 0.14 & 0.37 & -0.40 & 0.41 & 0.46 & 0.35 & 0.87 & 0.62 & 0.34 & 1.00 & & & & & \\
\hline $\mathrm{Mg}^{2+}$ & -0.25 & 0.50 & 0.50 & -0.46 & 0.85 & 0.87 & 0.25 & 0.91 & 0.55 & 0.44 & 0.60 & 1.00 & & & & \\
\hline $\mathrm{Cl}^{-}$ & -0.03 & 0.15 & 0.17 & -0.20 & 0.18 & 0.25 & 0.43 & 0.61 & 0.80 & 0.04 & 0.67 & 0.44 & 1.00 & & & \\
\hline $\mathrm{HCO}_{3}{ }^{-}$ & -0.15 & 0.06 & 0.41 & -0.39 & 0.70 & 0.71 & 0.01 & 0.70 & 0.64 & 0.63 & 0.58 & 0.66 & 0.21 & 1.00 & & \\
\hline $\mathrm{SO}_{4}{ }^{2-}$ & -0.18 & 0.47 & 0.39 & -0.34 & 0.15 & 0.12 & -0.07 & 0.11 & -0.08 & 0.20 & 0.01 & 0.17 & -0.10 & -0.02 & 1.00 & \\
\hline $\mathrm{NO}_{\underline{3}}^{-}$ & -0.34 & 0.70 & 0.54 & -0.50 & 0.44 & 0.43 & 0.43 & 0.61 & 0.43 & 0.40 & 0.48 & 0.60 & 0.40 & 0.32 & 0.38 & 1.00 \\
\hline
\end{tabular}


Table 7 R-mode factor loadings for shallow and deep groundwater parameters

\begin{tabular}{|c|c|c|c|c|}
\hline \multirow[t]{2}{*}{ Parameter } & \multicolumn{4}{|l|}{ Factor } \\
\hline & 1 & 2 & 3 & 4 \\
\hline SWL & -0.05 & -0.22 & -0.08 & -0.73 \\
\hline Temp & 0.18 & 0.87 & 0.01 & 0.01 \\
\hline $\mathrm{pH}$ & 0.24 & 0.83 & 0.15 & -0.02 \\
\hline Eh & -0.21 & -0.81 & -0.19 & 0.10 \\
\hline $\mathrm{EC}$ & 0.92 & 0.21 & 0.06 & 0.02 \\
\hline TDS & 0.92 & 0.19 & 0.13 & -0.01 \\
\hline DO & 0.01 & 0.51 & 0.40 & -0.60 \\
\hline $\mathrm{TH}$ & 0.67 & 0.28 & 0.58 & 0.05 \\
\hline $\mathrm{Na}^{+}$ & 0.40 & 0.09 & 0.77 & -0.04 \\
\hline $\mathrm{K}^{+}$ & 0.62 & -0.11 & 0.06 & 0.59 \\
\hline $\mathrm{Ca}^{2+}$ & 0.41 & 0.13 & 0.74 & 0.01 \\
\hline $\mathrm{Mg}^{2+}$ & 0.77 & 0.35 & 0.33 & 0.08 \\
\hline $\mathrm{Cl}^{-}$ & 0.05 & 0.07 & 0.93 & -0.05 \\
\hline $\mathrm{HCO}_{3}{ }^{-}$ & 0.81 & 0.01 & 0.28 & 0.12 \\
\hline $\mathrm{SO}^{2-}$ & 0.02 & 0.58 & -0.21 & 0.43 \\
\hline $\mathrm{NO}_{3}^{-}$ & 0.26 & 0.63 & 0.40 & 0.30 \\
\hline Eigenval & 6.87 & 2.34 & 2.00 & 1.09 \\
\hline$\%$ Total variance & 42.95 & 14.62 & 12.51 & 6.82 \\
\hline Cumul. eigenval & 6.87 & 9.21 & 11.21 & 12.30 \\
\hline \% Cumul total variance & 42.95 & 57.57 & 70.08 & 76.90 \\
\hline
\end{tabular}

\section{Drinking water quality}

The quality parameters of the groundwater samples were compared with WHO guidelines (WHO 1993, 2004) for drinking purpose (Table 3). The chemical analyses results show that based on most of the parameters, the water samples are good for drinking. However, the $\mathrm{pH}$ data indicates that 90 and $46 \%$ (Table 4) are not within the allowable limits of between 6.5 and 9.2 for drinking and domestic use. The recorded low values are in the range 3.3-6.4. Low $\mathrm{pH}$ values are attributed to humic acid from decaying vegetative matter. Drinking low $\mathrm{pH}$ water $(<4.0)$, could lead to redness and irritation of the eyes (WHO 1996). In addition, such low $\mathrm{pH}$ values affect the degree of corrosion of metals as well as disinfection efficiency, which may have indirect effect on health (WHO 1996). Therefore, it is recommended that neutralizing filter containing calcite or ground limestone be used to raise the $\mathrm{pH}$ of the groundwater before use by the population.

\section{Irrigation water quality}

The suitability of the water for irrigation is based on effects of mineral constituents of water for both the plants and soils. In general, excessive amount of dissolved ions in water used for irrigation will affect plants and soils thus reducing productivity (Bahar and Reza 2010). The results of the indices used for assessing the groundwater samples for irrigation use are presented in Table 8, while the classifications as irrigation was are shown in Table 9.

Electrical conductivity (EC) is a good measure of salinity hazard as it reflects the total dissolved solids (TDS) in water. Seventeen groundwater samples comprising 13 from upper layer and 4 from lower layer, exceeds the permissible limit $(<250 \mu \mathrm{S} / \mathrm{cm})$ for irrigation (Table 9). Excess EC may physically harm plant growth by limiting the uptake of water and nutrients through modification of osmotic processes (Todd 1980; Saleh et al. 1999) and chemically by metabolic reactions such as those caused by toxic constituents (Todd 1980). Using Wilcox Classification scheme, majority of the groundwater samples fall in the class $\mathrm{C}_{2} \mathrm{~S}_{1}$ (medium salinity, low sodium) and $\mathrm{C}_{1} \mathrm{~S}_{1}$ (low salinity, low sodium). Thus, these groundwater samples can be used to irrigate tolerant and semi-tolerant crops and most crops on most soils and moderate salt tolerant soil. However, salinity hazard is ruled out due to high infiltration capacity of the soil, which consist of silt, sand and gravelly sand (Jassas and Merkel 2015).

The total hardness (TH) varied between 0.66 and $114.30 \mathrm{mg} / \mathrm{l}$ for upper layer groundwater and from 0.66 to $297.6 \mathrm{mg} / \mathrm{l}$. According to the classification of Sawyer and McMcartly (1967), 16 (lower layer) and 6 (upper layer) groundwater samples fell under the category of soft water (Table 9). Three samples each from both upper and lower layers came under moderately hard category, while two samples from the upper layer are in the hard class. Hard water generally forms scale thereby clogging plumbing facilities. The hardness in these water samples can be removed by softening before supply to the public.

Sodium percentage (\% Na) is very important for classifying the irrigation water because sodium by process of ion exchange replaces calcium in soil thereby destroying the soil structure resulting in reduced permeability (Rao 2006). The \% Na data indicates that 73 and $63 \%$ of the samples from upper and lower layers are not suitable for irrigation (Table 9).

Sodium adsorption ratio (SAR) was also used to assess the groundwater for irrigation. SAR is used as a better measure (alkali) hazard in irrigation as SAR of water is directly related to the adsorption of sodium by soil and is a valuable criterion for determining the suitability of water for irrigation (Ravikumar et al. 2011). The SAR values range from 0.07 to 6.87 (upper layer) and 0.02-76.82 (lower layer) (Table 8), suggesting that all the samples are excellent for irrigation use (SAR $<10$, Table 9).

In terms of magnesium hazard $(\mathrm{MH})$, the water has no adverse effect on crop yield with $\mathrm{MH}<50 \%$ (Table 9). The magnesium ratio values show that, 53 and $55 \%$ of upper and lower groundwater samples were suitable for irrigation with $\mathrm{Mg} / \mathrm{Ca}<1.5 \mathrm{meq} / \mathrm{l}$ (Tables 8, 9). 
Table 8 Ionic ratios, irrigation and seawater intrusion assessment parameters

\begin{tabular}{|c|c|c|c|c|c|c|c|c|c|c|c|c|c|c|c|c|c|c|c|}
\hline $\begin{array}{l}\mathrm{S} / \\
\mathrm{N}\end{array}$ & $\begin{array}{l}\text { Sample } \\
\text { code }\end{array}$ & SAR & $\% \mathrm{Na}$ & $\begin{array}{l}\text { MH } \\
\%\end{array}$ & $\mathrm{KI}$ & RSC & $\begin{array}{l}\text { PI } \\
\%\end{array}$ & $\mathrm{RC}$ & $\begin{array}{l}\mathrm{Mg} / \\
\mathrm{Ca}\end{array}$ & $\begin{array}{l}\mathrm{HCO}^{-} / \\
\mathrm{Cl}^{-}\end{array}$ & $\begin{array}{l}\mathrm{Na}+/ \\
\mathrm{Cl}^{-}\end{array}$ & $\begin{array}{l}\mathrm{Na}+/ \\
\mathrm{Ca}^{2+}\end{array}$ & $\begin{array}{l}\mathrm{Ca}^{2+} / \\
\mathrm{Cl}^{-}\end{array}$ & $\begin{array}{l}\mathrm{K}^{+} / \\
\mathrm{Cl}^{-}\end{array}$ & $\begin{array}{l}\mathrm{Cl}^{-} / \\
\mathrm{HCO}_{3}^{-}\end{array}$ & $\begin{array}{l}\mathrm{Mg}^{2+} / \\
\mathrm{Cl}^{-}\end{array}$ & $\begin{array}{l}\mathrm{Ca}^{2+} / \\
\mathrm{SO}^{2-}\end{array}$ & $\begin{array}{l}\mathrm{SO}^{2-}{ }^{2-} \\
\mathrm{Cl}^{-}\end{array}$ & SMI \\
\hline 1 & AK 07 & 0.72 & 61.35 & 62.25 & 0.99 & 0.00 & 187.55 & 0.86 & 1.65 & 1.16 & 1.16 & 2.62 & 0.44 & 0.70 & 0.86 & 0.73 & 0.80 & 0.55 & 0.12 \\
\hline 2 & AK 08 & 4.74 & 70.30 & 36.17 & 2.12 & 1.27 & 108.66 & 0.48 & 0.57 & 2.08 & 2.19 & 3.32 & 0.66 & 0.25 & 0.48 & 0.37 & 9.58 & 0.07 & 1.75 \\
\hline 3 & AK 09 & 0.37 & 24.16 & 19.83 & 0.26 & -0.20 & 107.21 & 0.29 & 0.25 & 3.49 & 1.54 & 0.33 & 4.72 & 0.33 & 0.29 & 1.17 & 3.19 & 1.48 & 0.12 \\
\hline 4 & AK 10 & 2.06 & 70.14 & 95.37 & 2.22 & 0.10 & 149.33 & 0.81 & 20.61 & 1.23 & 1.89 & 47.94 & 0.04 & 0.11 & 0.81 & 0.81 & 0.07 & 0.58 & 0.36 \\
\hline 5 & AK 11 & 2.47 & 58.50 & 41.40 & 1.13 & 0.53 & 104.71 & 0.57 & 0.71 & 1.75 & 1.37 & 1.93 & 0.71 & 0.34 & 0.57 & 0.50 & 6.71 & 0.11 & 1.05 \\
\hline 6 & AK 12 & 3.45 & 55.37 & 64.69 & 1.14 & 1.40 & 92.47 & 0.19 & 1.83 & 5.24 & 3.71 & 3.23 & 1.15 & 0.33 & 0.19 & 2.10 & 12.93 & 0.09 & 1.61 \\
\hline 7 & AK 13 & 1.32 & 69.49 & 67.95 & 2.00 & 0.07 & 196.70 & 0.78 & 2.12 & 1.28 & 1.54 & 6.23 & 0.25 & 0.22 & 0.78 & 0.53 & 1.68 & 0.15 & 0.16 \\
\hline 8 & AK 14 & 1.59 & 44.01 & 75.14 & 0.72 & 0.39 & 102.73 & 0.39 & 3.02 & 2.57 & 1.40 & 2.91 & 0.48 & 0.12 & 0.39 & 1.46 & 7.19 & 0.07 & 0.71 \\
\hline 9 & AK 15 & 2.30 & 65.66 & 51.73 & 1.79 & -0.38 & 79.84 & 27.49 & 1.07 & 0.04 & 0.82 & 3.70 & 0.22 & 0.06 & 27.49 & 0.24 & 3.19 & 0.07 & 0.71 \\
\hline 10 & AK 21 & 0.07 & 18.29 & 66.65 & 0.05 & -0.33 & 82.91 & 1.55 & 2.00 & 0.65 & 0.10 & 0.16 & 0.65 & 0.33 & 1.55 & 1.30 & 1.32 & 0.49 & 0.15 \\
\hline 11 & AK 22 & 0.76 & 90.63 & 62.25 & 3.29 & 0.02 & 395.97 & 2.58 & 1.65 & 0.39 & 0.51 & 8.72 & 0.06 & 1.00 & 2.58 & 0.10 & 0.80 & 0.07 & 0.05 \\
\hline 12 & AK 23 & 0.28 & 21.83 & 48.12 & 0.11 & -0.72 & 63.02 & 0.69 & 0.93 & 1.45 & 0.31 & 0.22 & 1.42 & 0.45 & 0.69 & 1.31 & 9.58 & 0.15 & 0.35 \\
\hline 13 & AK 24 & 0.35 & 26.20 & 58.76 & 0.18 & 0.22 & 109.87 & 0.19 & 1.42 & 5.31 & 0.77 & 0.43 & 1.79 & 0.77 & 0.19 & 2.56 & 3.53 & 0.51 & 0.22 \\
\hline 14 & AK 25 & 0.36 & 30.43 & 73.00 & 0.19 & -0.06 & 100.73 & 0.58 & 2.70 & 1.71 & 0.34 & 0.70 & 0.49 & 0.45 & 0.58 & 1.33 & 2.99 & 0.16 & 0.33 \\
\hline 15 & AK 26 & 1.28 & 44.49 & 17.34 & 0.79 & -0.17 & 103.14 & 0.82 & 0.21 & 1.21 & 1.29 & 0.95 & 1.35 & 0.03 & 0.82 & 0.28 & 8.78 & 0.15 & 0.42 \\
\hline 16 & AK 27 & 2.71 & 74.10 & 14.15 & 2.81 & -0.02 & 125.89 & 2.38 & 0.16 & 0.42 & 1.29 & 3.27 & 0.39 & 0.03 & 2.38 & 0.06 & 3.19 & 0.12 & 0.51 \\
\hline 17 & AK 28 & 5.23 & 69.60 & 48.51 & 2.24 & -0.96 & 83.43 & 8.31 & 0.94 & 0.12 & 0.93 & 4.36 & 0.21 & 0.02 & 8.31 & 0.20 & 11.18 & 0.02 & 2.70 \\
\hline 18 & AK 29 & 3.11 & 52.18 & 38.80 & 1.07 & -0.48 & 80.84 & 1.55 & 0.63 & 0.65 & 0.89 & 1.74 & 0.51 & 0.02 & 1.55 & 0.32 & 31.14 & 0.02 & 2.07 \\
\hline 19 & AK 30 & 1.45 & 45.70 & 13.28 & 0.81 & 0.26 & 115.55 & 0.56 & 0.15 & 1.80 & 1.10 & 0.93 & 1.18 & 0.04 & 0.56 & 0.18 & 13.41 & 0.09 & 0.54 \\
\hline 20 & AK 01 & 77.23 & 99.63 & 76.73 & 263.69 & 1.49 & 121.26 & 2.61 & 3.30 & 0.38 & 1.43 & 1133.19 & 0.00 & 0.04 & 2.61 & 0.00 & 0.60 & 0.00 & 4.14 \\
\hline 21 & AK 02 & 6.81 & 96.95 & 62.25 & 29.62 & 0.18 & 206.33 & 1.00 & 1.65 & 1.00 & 1.99 & 78.45 & 0.03 & 0.14 & 1.00 & 0.04 & 2.40 & 0.01 & 0.26 \\
\hline 22 & AK 03 & 4.07 & 71.05 & 80.32 & 2.32 & 0.30 & 110.35 & 0.71 & 4.08 & 1.40 & 2.34 & 11.80 & 0.20 & 0.13 & 0.71 & 0.81 & 1.45 & 0.14 & 1.18 \\
\hline 23 & AK 04 & 1.71 & 37.69 & 60.11 & 0.56 & -1.59 & 59.58 & 2.10 & 1.51 & 0.48 & 0.84 & 1.41 & 0.60 & 0.07 & 2.10 & 0.90 & 7.43 & 0.08 & 1.30 \\
\hline 24 & AK 05 & 5.86 & 93.69 & 49.73 & 13.15 & 0.36 & 184.11 & 0.96 & 0.99 & 1.04 & 1.65 & 26.15 & 0.06 & 0.21 & 0.96 & 0.06 & 1.09 & 0.06 & 0.46 \\
\hline 25 & AK 06 & 1.77 & 93.11 & 62.25 & 7.70 & 0.04 & 281.35 & 1.72 & 1.65 & 0.58 & 1.20 & 20.40 & 0.06 & 0.91 & 1.72 & 0.10 & 0.48 & 0.12 & 0.08 \\
\hline 26 & AK 16 & 0.08 & 2.96 & 49.73 & 0.02 & -1.67 & 39.78 & 0.64 & 0.99 & 1.55 & 0.08 & 0.04 & 1.77 & 0.03 & 0.64 & 1.75 & 14.37 & 0.12 & 0.46 \\
\hline 27 & AK 17 & 0.02 & 4.25 & 50.75 & 0.01 & -0.64 & 61.49 & 0.72 & 1.03 & 1.40 & 0.02 & 0.02 & 1.13 & 0.08 & 0.72 & 1.17 & 5.47 & 0.21 & 0.34 \\
\hline 28 & AK 18 & 0.05 & 2.17 & 50.26 & 0.01 & -1.80 & 37.69 & 0.75 & 1.01 & 1.33 & 0.04 & 0.03 & 1.57 & 0.03 & 0.75 & 1.59 & 8.25 & 0.19 & 0.52 \\
\hline 29 & AK 19 & 0.15 & 5.95 & 35.47 & 0.04 & -1.92 & 38.41 & 0.98 & 0.55 & 1.02 & 0.09 & 0.06 & 1.48 & 0.05 & 0.98 & 0.81 & 13.47 & 0.11 & 0.74 \\
\hline 30 & AK 20 & 2.19 & 71.92 & 21.56 & 2.51 & 0.14 & 157.04 & 0.69 & 0.27 & 1.45 & 2.12 & 3.20 & 0.66 & 0.05 & 0.69 & 0.18 & 2.40 & 0.28 & 0.32 \\
\hline
\end{tabular}

Upper layer (nos. 1-19) and lower layer (nos. 20-30)

$E C$ electrical conductivity, $T H$ total hardness, $S A R$ sodium adsorption ratio, \% $N a$ percent sodium, $M H$ magnesium hazard, $R C$ Revelle coefficient

Residual sodium carbonate (RSC) is another parameter used to assess the quality of water for irrigation use. This based on the presence of carbonate and bicarbonate, along the content of calcium and magnesium. The water unfit for irrigation will precipitate calcite in soil from solution and increase sodium in solution resulting in soil dispersion (Emerson and Bakker 1973) as well as impair nutrient uptake by plants (Kanwar and Chaudhry 1968). The RSC values varied from -0.97 to 1.38 (upper layer) and -5.99 to 3.13 (lower layer) (Table 8), with 89 and $82 \%$ of upper and lower groundwater samples having RSC values less than $1.25 \mathrm{meq} / \mathrm{l}$ indicating good water quality for agriculture (Table 9).

\section{Permeability index (PI)}

When the concentration of sodium is high in irrigation water, it tends to be adsorbed by clay particles displacing calcium and magnesium. The exchange process of sodium in water for calcium and magnesium in soil reduces the permeability resulting in soil with poor drainage including poor air and water circulation (Collins and Jenkins 1996; Saleh et al. 1999). The range of PI for upper and lower groundwater samples varied from 80.64 to $789.39 \mathrm{meq} / \mathrm{l}$ for upper layer groundwater and from 3.00 to $306.61 \mathrm{meq} / \mathrm{l}$ for lower groundwater layer. These values of PI indicate poor through moderate to good water for irrigation (Table 9).

\section{Kelly's index (KI)}

Kelly's index in the present study varied as follows: 0.05-3.26 for upper groundwater layer and 0.01-261.02 for lower groundwater layer (Table 8 ). These ranges of values indicate that 53 and $64 \%$ of the groundwater samples are unsuitable for irrigation in respect of the upper and lower layers as presented in Table 9 . 
Table 9 Irrigation water and seawater classification

\begin{tabular}{|c|c|c|c|c|c|c|c|c|}
\hline \multirow[t]{2}{*}{ Purpose } & \multirow[t]{2}{*}{ Parameters } & \multirow[t]{2}{*}{ Units } & \multirow{2}{*}{$\begin{array}{l}\text { Class } \\
\text { range }\end{array}$} & \multirow[t]{2}{*}{ Classification } & \multicolumn{2}{|l|}{ No } & \multicolumn{2}{|l|}{$\%$} \\
\hline & & & & & Upper & Lower & Upper & Lower \\
\hline \multirow[t]{41}{*}{ Irrigation } & Electrical conductivity (EC) & $\mu \mathrm{S} /$ & $<250$ & Excellent & 6 & 7 & 32 & 64 \\
\hline & Ragunath (1987) & $\mathrm{cm}$ & $250-750$ & Good & 12 & 2 & 63 & 18 \\
\hline & & & $750-2000$ & Permissible & 1 & 2 & 5 & 18 \\
\hline & & & $2000-3000$ & Doubtful & & & & \\
\hline & & & $>3000$ & Unsuitable & & & & \\
\hline & Total hardness $(\mathrm{TH})$ & $\mathrm{mg} / \mathrm{l}$ & $<75$ & Soft & 16 & 6 & 84 & 55 \\
\hline & Sawyer and McMcartly (1967) & & $75-150$ & Moderately hard & 3 & 3 & 16 & 27 \\
\hline & & & $150-300$ & Hard & & 2 & & 18 \\
\hline & & & $>300$ & Very hard & & & & \\
\hline & Sodium adsorption ratio (SAR) & & $<10$ & Excellent & 19 & 10 & 100 & 91 \\
\hline & Richards (1954) & & $10-18$ & Good & & & & \\
\hline & & & $18-26$ & Doubtful & & & & \\
\hline & & & $>26$ & Unsuitable & & 1 & & 9 \\
\hline & Percent sodium $(\% \mathrm{Na})$ & $\%$ & $<20$ & Excellent & 1 & 4 & 5 & 36 \\
\hline & Ragunath (1987) & & $20-40$ & Good & 4 & 1 & 21 & \\
\hline & & & $40-60$ & Permissible & 6 & & 32 & \\
\hline & & & $60-80$ & Doubtful & 7 & 2 & 37 & 18 \\
\hline & & & $>80$ & Unsuitable & 1 & 4 & 5 & 36 \\
\hline & Magnesuim hazard & $\%$ & $<50$ & Suitable & 8 & 3 & 42 & 27 \\
\hline & Paliwal (1972) & & $>50$ & Unsuitable & 11 & 8 & 58 & 73 \\
\hline & RSC & & $<1.25$ & Good & 17 & 10 & 89 & 91 \\
\hline & Richards (1954) & & $1.25-2.5$ & Doubtful & 2 & 1 & 11 & 9 \\
\hline & & & $>2.5$ & Unsuitable & & & & \\
\hline & PI $(\%)$ & & $>75$ & Suitable & 18 & 6 & 95 & 55 \\
\hline & Doneen (1964) & & $75-25$ & Moderate & 1 & & 5 & \\
\hline & & & $<25$ & Not suitable & & 5 & & 45 \\
\hline & KI & & $<1$ & Suitable & 9 & 5 & 47 & 45 \\
\hline & Kelly (1940) & & $>1$ & Not suitable & 10 & 6 & 53 & 55 \\
\hline & $\mathrm{Mg} / \mathrm{Ca}$ & & $<1.5$ & Safe & 11 & 6 & 58 & 55 \\
\hline & Ravikumar et al. (2011) & & $1.5-3.0$ & Moderate & 6 & 3 & 32 & 27 \\
\hline & & & $>3.0$ & Not suitable & 2 & 2 & 11 & 18 \\
\hline & $\mathrm{Cl}$ & & $<142$ & Excellent & 19 & 11 & 100 & 100 \\
\hline & Sagnak (1991), Bauder et al. (2004), Hopkins et al. & & $142-249$ & Good & & & & \\
\hline & 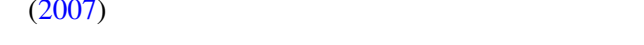 & & $249-426$ & Permissible & & & & \\
\hline & & & $426-710$ & Precaution usable & & & & \\
\hline & & & $>710$ & Unsuitable & & & & \\
\hline & $\mathrm{SO}_{4}$ & & $<192$ & Excellent & 19 & 11 & 100 & 100 \\
\hline & Sagnak (1991), Bauder et al. (2004), Hopkins et al. & & $192-336$ & Good & & & & \\
\hline & $(2007)$ & & $336-575$ & Permissible & & & & \\
\hline & & & $575-960$ & Precaution usable & & & & \\
\hline & & & $>960$ & Unsuitable & & & & \\
\hline
\end{tabular}


Table 9 continued

\begin{tabular}{|c|c|c|c|c|c|c|c|c|}
\hline \multirow[t]{2}{*}{ Purpose } & \multirow[t]{2}{*}{ Parameters } & \multirow[t]{2}{*}{ Units } & \multirow{2}{*}{$\begin{array}{l}\text { Class } \\
\text { range }\end{array}$} & \multirow[t]{2}{*}{ Classification } & \multicolumn{2}{|l|}{ No } & \multicolumn{2}{|l|}{$\%$} \\
\hline & & & & & Upper & Lower & Upper & Lower \\
\hline \multirow{6}{*}{$\begin{array}{l}\text { Seawater } \\
\text { pollution }\end{array}$} & Revelle coefficient (RC) & & $<1$ & Freshwater & 13 & 7 & 68 & 64 \\
\hline & Kallergis (1986) & & $1.0-2.0$ & Slightly polluted & 2 & 2 & 11 & 18 \\
\hline & & & $2.0-6.0$ & $\begin{array}{l}\text { Moderately } \\
\text { polluted }\end{array}$ & 2 & 2 & 11 & 18 \\
\hline & & & $6.0-10.0$ & Seriously & 1 & & 5 & \\
\hline & & & $10.0-150.0$ & Dangerously & 1 & & 5 & \\
\hline & & & $>150.0$ & Seawater & & & & \\
\hline
\end{tabular}

Table 10 Correlation between TDS, SMI and ionic ratios

\begin{tabular}{|c|c|c|c|c|c|c|c|c|c|c|c|}
\hline & TDS & $\mathrm{HCO}_{3}{ }^{-} / \mathrm{CI}^{-}$ & $\mathrm{Na}^{+} / \mathrm{Cl}^{-}$ & $\mathrm{Na}^{+} / \mathrm{Ca}^{2+}$ & $\mathrm{Ca}^{2+} / \mathrm{Cl}^{-}$ & $\mathrm{K}^{+} / \mathrm{Cl}^{-}$ & $\mathrm{Cl}^{-} / \mathrm{HCO}_{3}{ }^{-}$ & $\mathrm{Mg}^{2+} / \mathrm{Cl}^{-}$ & $\mathrm{Ca}^{2+} / \mathrm{SO}_{4}{ }^{2-}$ & $\mathrm{SO}_{4}{ }^{2-} / \mathrm{Cl}^{-}$ & SMI \\
\hline TDS & 1.00 & & & & & & & & & & \\
\hline $\mathrm{HCO}_{3}{ }^{-} / \mathrm{Cl}^{-}$ & -0.21 & 1.00 & & & & & & & & & \\
\hline $\mathrm{Na}^{+} / \mathrm{Cl}^{-}$ & -0.03 & 0.38 & 1.00 & & & & & & & & \\
\hline $\mathrm{Na}^{+} / \mathrm{Ca}^{2+}$ & -0.02 & -0.18 & 0.09 & 1.00 & & & & & & & \\
\hline $\mathrm{Ca}^{2+} / \mathrm{Cl}^{-}$ & -0.09 & 0.54 & -0.15 & -0.19 & 1.00 & & & & & & \\
\hline $\mathrm{K}^{+} / \mathrm{Cl}^{-}$ & -0.04 & 0.24 & -0.06 & -0.14 & -0.01 & 1.00 & & & & & \\
\hline $\mathrm{Cl}^{-} / \mathrm{HCO}_{3}{ }^{-}$ & 0.22 & -0.35 & -0.12 & 0.01 & -0.21 & -0.15 & 1.00 & & & & \\
\hline $\mathrm{Mg}^{2+} / \mathrm{Cl}^{-}$ & -0.16 & 0.73 & -0.15 & -0.24 & 0.49 & 0.16 & -0.25 & 1.00 & & & \\
\hline $\mathrm{Ca}^{2+} / \mathrm{SO}_{4}{ }^{2-}$ & -0.05 & 0.08 & -0.12 & -0.19 & 0.19 & -0.37 & -0.07 & 0.12 & 1.00 & & \\
\hline $\mathrm{SO}_{4}{ }^{2-} / \mathrm{Cl}^{-}$ & 0.16 & 0.38 & 0.01 & -0.14 & 0.72 & 0.22 & -0.16 & 0.32 & -0.28 & 1.00 & \\
\hline SMI & 0.19 & -0.14 & 0.23 & 0.69 & -0.24 & -0.38 & 0.13 & -0.22 & 0.32 & -0.36 & 1.00 \\
\hline
\end{tabular}

\section{Chloride and sulphate}

Chloride and sulphate have also been used for assessment of suitability of water for irrigation (Sagnak 1991; Bauder et al. 2004; Hopkins et al. 2007). Chloride is an essential element for plants and also an important criterion for agriculture water. Sulphate is necessary for plant nutrition, but water containing more than $1000 \mathrm{ppm}$ of sulphate is not good for plants with respect to adsorbing calcium (Sagnak 1991). It has been observed that with respect to chloride and sulphate for the water samples under consideration are in class of excellent water (Table 9).

\section{Identification of seawater pollution using ionic ratios and seawater mixing index (SMI)}

Ionic ratios have often been used to evaluate seawater intrusion in coastal areas (Sánchez-Martos et al. 2002; Kim et al. 2003; El Moujabber et al. 2006; Lee and Song 2007). Table 8 contains some ionic ratio values of water, while Table 10 contains the correlation between TDS and these ratios. The values of $\mathrm{HCO}_{3}{ }^{-} / \mathrm{Cl}^{-}$, indicative of freshwater recharge are all greater than seawater ratio (0.03)
(Table 8). Thus the ratio can be a good indicator for salinization due to seawater encroachment. The ratios of $\mathrm{Na}^{+} / \mathrm{Cl}^{-}$showed significant correlation with TDS $(r=0.73)$ (Table 8) and similar to seawater. Thus the ratio may be good indicator of sea water intrusion.

Ratios of $\mathrm{Na}^{+} / \mathrm{Ca}^{2+}, \mathrm{Ca}^{2+} / \mathrm{Cl}^{-}, \mathrm{K}^{+} / \mathrm{Cl}^{-}$and $\mathrm{Ca}^{2+} /$ $\mathrm{HCO}_{3}{ }^{-}$showed weak correlation with TDS (Table 10). Therefore it may not be a good indicator for evaluating seawater intrusion. The ratio $\mathrm{Mg}^{2+} / \mathrm{Cl}^{-}$showed moderate positive correlation ( $r=0.63$ ) with TDS. Thus high $\mathrm{Mg}^{2+} /$ $\mathrm{Cl}^{-}$ratio indicate high TDS and hence effect of seawater intrusion. $\mathrm{Ca}^{2+} / \mathrm{SO}_{4}{ }^{2-}$ and $\mathrm{SO}_{4}^{2} / \mathrm{Cl}^{-}$showed a poor correlation with TDS. Thus low $\mathrm{Ca}^{2+} / \mathrm{SO}_{4}{ }^{2-}$ and $\mathrm{SO}_{4}^{2} / \mathrm{Cl}^{-}$ indicated low TDS and hence not a good criteria to indicate effect of seawater intrusion. Therefore, $\mathrm{Na}^{+} / \mathrm{Cl}^{-}$, and $\mathrm{Mg}^{2+} / \mathrm{Cl}^{-}$ratios are good indicator of seawater pollution.

Also chloride-bicarbonate ratio (or Revelle coefficient, $\mathrm{R})$ was used as a criterion to evaluate seawater intrusion. The Revelle coefficient $(\mathrm{R})$ is defined as: $\mathrm{Cl}^{-} / \mathrm{CO}_{3}{ }^{2-}+-$ $\mathrm{HCO}_{3}{ }^{-}$. Most of the groundwater samples from the upper (89\%) and lower (73\%) layers were characterized as fresh water and slightly polluted (Table 8). One sample each from the different layers were classified as moderately and dangerously polluted, while one lower layer sample was 
categorized as being seriously polluted. According to the above, some level of seawater pollution took place in seven groundwater locations.

The principles of the seawater mixing index (SMI) proposed by Park et al. (2005) was also adopted in the present work to estimate the relative degree of brackish water mixing with freshwater. The value of SMI can be computed as follows:

$\mathrm{SMI}=a \times \frac{C_{\mathrm{Na}}}{T_{\mathrm{Na}}}+b \times \frac{C_{\mathrm{Mg}}}{T_{\mathrm{Mg}}}+c \times \frac{C_{\mathrm{Cl}}}{T_{\mathrm{Cl}}}+d \times \frac{C_{\mathrm{SO} 4}}{T_{\mathrm{SO} 4}}$,

where $a, b, c$ and $d$ denote the relative degree concentration proportion of $\mathrm{Na}, \mathrm{Mg}, \mathrm{Cl}$, and $\mathrm{SO}_{4}$ in seawater, respectively ( $a=0.31, b=0.04, c=0.57, d=0.08$ ); $C$ is the measured concentration in groundwater with units in $\mathrm{mg} / \mathrm{l}$; $T$ represents the regional threshold values estimated from the interpretation of the probability curves (Sinclair 1974, 1976). If the SMI is greater than 1, the water may then be considered to obviously record the effect of seawater mixing. The computed threshold values for $\mathrm{Na}, \mathrm{Mg}$, $\mathrm{Cl}$, and $\mathrm{SO}_{4}$ were as follows $15,7.5,55$ and $22.5 \mathrm{mg} / \mathrm{l}$. The threshold values were then used to compute the SMI (Table 8). The data showed that three locations each from the upper (AK 08, AK 11, AK 12) and lower (AK 01, AK 03 , AK 04) layers had SMI $>1$. This suggests that these wells were affected by seawater. This is also supported by the positive correlation between SMI and TDS with a correlation coefficient of 0.78 (Table 10).

One explanation is that during high tide, creek and creeklets become filled with brackish water and thus recharging aquifers with brackish water. The wells are not affected by sea water intrusion due to the fact that aquifers are not well recharged (Diamantis and Petalas 1989).

\section{Conclusions}

1. The area is underlain by prolific aquifer characterized by high hydraulic conductivity and transmissivity.

2. The groundwater is fit for drinking and domestic use based on the World Health Organization allowable limits. However, more than $70 \%$ of the $\mathrm{pH}$ values are not within the allowable limits. Therefore, it is recommended that neutralizing filter containing calcite or ground limestone should be applied to raise the $\mathrm{pH}$ before use.

3. The dominant groundwater types in the area are $\mathrm{Na}^{+}$$\mathrm{HCO}_{3}{ }^{-}$for the upper part of the aquifer and $\mathrm{Na}^{+}-\mathrm{Cl}^{-}$ for the lower part of the aquifer. These groundwater types are attributable to silicate weathering and tidal flushing, respectively.

4. Multivariate statistics reveal the main geochemical process controlling the groundwater chemistry as silicate weathering due to high $\mathrm{Na}^{+}$and $\mathrm{HCO}_{3-}$; contributions from humic acid indicated by low $\mathrm{pH}$ and poor waste management indicated by low DO and high $\mathrm{K}$.

5. Sodium adsorption ratio (SAR), magnesium hazard $(\mathrm{MH})$ and magnesium ratio indicated the excellent quality of these waters for irrigation use. However, with respect to other parameters, most of the groundwater can be used for irrigation of crops on all types of soils and moderate salt tolerant crops.

6. Total dissolved solids and ratios of $\mathrm{Na}^{+} / \mathrm{Cl}^{-}, \mathrm{Mg}^{2+} / \mathrm{Cl}^{-}$, and $\mathrm{Ca}^{2+} / \mathrm{SO}_{4}{ }^{2-}$ and saltwater mixing index (SMI) suggest some level of seawater intrusion in the area.

7. The coastal parts of Akwa Ibom State, the study area is the economic base of the state and Nigeria in general through marine and oil/gas activities. However, to date no concrete effort has been put in place to assess the quality and quantity of the potable water in the area. Therefore, this work forms a basis in this aspect.

Open Access This article is distributed under the terms of the Creative Commons Attribution 4.0 International License (http:// creativecommons.org/licenses/by/4.0/), which permits unrestricted use, distribution, and reproduction in any medium, provided you give appropriate credit to the original author(s) and the source, provide a link to the Creative Commons license, and indicate if changes were made.

\section{References}

Al-Shaibani AM (2008) Hydrogeology and hydrochemistry of a shallow alluvial aquifer, Western Saudi Arabia. Hydrogeol J 16:155-165

APHA (1995) Standard methods for the examination of water and waste water, 19th edn. American Public Health Association, Washington DC

Appelo CAJ, Postma D (1993) Geochemistry, groundwater and pollution. AA Balkema, Rotterdam

Bahar, MM, Reza, MS (2010) Hydrochemical characteristics and quality assessment of shallow groundwater in a coastal area of southwest Bangladesh. Environ Earth Sci 61:1065-1073

Bauder TA, Waskom RM, Davis JG (2004) Irrigation water quality criteria. Colorado State University, Cooperative Extension, Fact sheet No 0.506. http://uwadmnweb.uwyo.edu/soilfert/Pubs/ Irrigation\%20water\%20quality20CSU.pdf

Bear J (1979) Hydraulic of groundwater. McGraw-Hill International Book, New York

Chandrasekhar N, Selvakumar S, Srinvas Y, John Wilson JS, Simon Peter T, Magesh NS (2014) Hydrogeochemical assessment of groundwater quality along the coastal aquifers of southern Tamil Nadu, India. Environ Earth Sci 71:4739-4750

Chidambaram S, Kumar GS, Prasanna MV, Peter AJ, Ramanthan AL, Srinivasamoorthy (2008) A study on the hydrogeology and hydrogeochemistry of groundwater from different depths in coastal aquifers: Annamalai Nagar. Environ Geol, Tamilnadu. doi:10.1007/s00254-008-1282-4

Collins R, Jenkins A (1996) The impact of agricultural land use of stream chemistry in the middle hills of the Himalayas, Nepal. J Hydrol 185:71-86

Davis SN, Dewiest RJ (2006) Hydrogeology. Wiley, New York 
Diamantis JB, Petalas CP (1989) Seawater intrusion into coastal aquifers of Thrace and its impact on the environment. Toxicol Environ Chem 20-21:291-305

Doneen LD (1964) Notes on water quality in Agriculture. Published as a water science and engineering paper, 4001, Department of Water Science and Engineering, University of California

Eaton EM (1950) Significance of carbonate in irrigation water. Soil Sci 69:123-133

Edet AE (1993) Groundwater quality assessment in parts of eastern Niger delta, Nigeria. Environ Geol 22:41-46

Edet AE, Okereke CS (2001) A regional study of saltwater intrusion in southeastern Nigeria based on analysis of geoelectrical and hydrochemical data. Environ Geol 40(10):1278-1289

El Moujabber M, Bou Samra B, Darwish T, Atallah T (2006) Comparison of different indicators for groundwater contamination by seawater intrusion on the Lebanese Coast. Water Resour Manage 20:161-180

Emerson WW, Bakker AC (1973) The comparative effect of exchangeable $\mathrm{Ca}, \mathrm{Mg}$ and $\mathrm{Na}$ on some soil physical properties of red brown earth soils 2. The spontaneous dispersion of aggregates in water. Aust J Soil Res 11:151-152

Esu EO, Okereke CS, Edet AE (1999) A Regional hydrostratigrahic study of Akwa Ibom State, southeastern Nigeria Global. J Pure Appl Sci 5(1):89-96

Fetters CW (2001) Applied hydrogeology, 4th edn. Prentice Hall Englewood Cliffs, NJ, pp 598

Foster S (1998) Groundwater assessing vulnerability and promotion protection of a threatened resource. In: Proceedings of 8th Stockholm water symposium, Sweden, pp 79-90

GSN (1962) Nigerian geological map series. Sheets 79 (Umuahia) and 82 (Calabar)

Hopkins BG, Horneck DA, Stevens RG, Ellsworth JW (2007) Irrigation water quality in the Pacific Northwest, PNW 597-E Pacific Northwest Extension, Oregon State University, University of Idaho, Washington State University. http://extension. oregonstate.edu/catalog/pdf/pnw/pnw597-e.pdf

Jassas H, Merkel B (2015) Assessment of hydrochemical evolution of groundwater and its suitability for drinking and irrigation purposes in Al-Khazir Gomal Basin. Environ Earth Sci online, Northern Iraq. doi:10.007/S12665-015-4664-4

Jeong CH (2001) Effect of landuse and urbanization on hydrochemistry and contamination of groundwater from Taejon area, Korea. J Hydrol 253:194-210

Kallergis GA (1986) Applied hydrogeology TEE (TCG), Athens

Kanwar JS, Chaudhry ML (1968) Effect of Mg on the uptake of nutrients from soil. J Res Pb Agric Univ 3:309-319

Kelly WP (1940) Permissible composition and concentration of irrigated waters. In: Proceeding of the ASCF 66, pp 607

Kim JH, Yum BW, Kim RH, Koh DC, Cheong TJ, Lee JH, Chang HW (2003) Application of cluster analysis for the hydrogeological factors of saline groundwater in Kimje, Korea. Geosci J 7(4):313-322

Krásńy J (1993) Classification of transmissivity magnitude and variation. Groundwater 31:230-236

Lee JY, Song SH (2007) Evaluation of groundwater quality in coastal areas: implications for sustainable agriculture. Environ Geol 52:1231-1242

Matalas CN, Reiher JB (1967) Some comments on the use of factor analysis. Wat Res 3:33-139

Mondal NC, Singh VS, Rangarajan R (2009) Aquifer characteristics and its modeling around an industrial complex, Tuticorin, Tamil Nadu, India: a case study. J Earth Syst Sci 118(3):231-244

Nickson R, McArthur JM, Shrestha B, Kyaw-Myint TO, Lowry D (2005) Arsenic and other drinking water quality issues, Muzaffargarh District, Pakistan. Appl Geochem 20:55-68
Owolabi A, Obot AU (1998) Quality of groundwater in the coastal plain sands aquifer of the Akwa Ibom State, Nigeria. J Afr Earth Sci 27(2):259-275

Paliwal KV (1967) Effect of gypsum application on the quality of irrigation waters. Madras Agric J 59:646-647

Paliwal KV (1972) Irrigation with saline water. IARI, New delhi

Park S, Yun S, Chae G, Yoo I, Shin K, Heo C, Lee S, (2005) Regional hydrochemical study on salinization of coastal aquifers, western coastal area of South Korea. J Hydrol 313:182-194

Petters SW (1982) Central West African cretaceous - tertiary benthic foraminifera and stratigraphy. Paloeontograph A. 179:1-104

Petters SW (1989) Akwa Ibom State: physical background, soil and landuse and ecological problems. Technical Report for Government of Akwa Ibom State, pp 603

Ragunath HM (1987) Groundwater. Wiley Eastern Ltd, New Delhi

Raju JN, Shukla PR (2011) Hydrogeochemistry for the assessment of groundwater quality in Varanasi: a fast urbanizing center in Uttar Pradesh, India. Environ Monit Assess 173:279-300

Rao NS (2006) Seasonal variation of groundwater quality in parts of Guntur District, Andhra Pradesh, India. Environ Geol 49:413-429

Ravikumar P, Venkatesharaju K, Prakash KL, Somashekar RK (2011) Geochemistry of groundwater prospects evaluation, Anekal Tuluk, Bangalore Urban District, Karnataka, India. Environ Monit Assess 179:93-112

Richards LA (1954). Diagnosis and improvement of saline alkali soils. US Department of Agriculture, Handbook 60

Sagnak C (1991) Groundwater pollution originated from Geological formation: example of Konya-Çumra-Karapinar plain with GIS application. Department of Geotechnical Services DSI, Ankara, Turkey

Saleh A, Al- Shehata M (1999) Hydrogeochemical processes operating within the main aquifers of Kuwait. J Arid Environ 42:195-209

Sánchez-Martos F, Pulido-Bosch A, Molina-Sánchez L, VallejosIzquierdo A (2002) Identification of the origin of salinization in groundwater using minor ions (Lower Andarax, Southeast Spain). Sci Total Environ 297:43-58

Sawyer GN, McMcartly DL (1967) Chemistry of sanitary engineers, 2nd edn. McGraw Hill, New York

Sawyer GN, McMcartly DL, Parkin GF (2003) Chemistry of environmental engineering and science, 5th edn. McGraw Hill, New York

Saxena VK, Mondal NC, Singh VS (2004) Evaluation of hydrogeochemical parameters to delineate freshwater zones in coastal aquifers. J Appl Geochem 6:245-254

Sinclair AJ (1974) Selection of thresholds in geochemical data using probability graphs. J Geochem Explor 3:129-149

Sinclair AJ (1976) Application of Probability graphs in mineral exploration. Association of Exploration Geochemists, Rexdale, Ont. pp 95

Tahal (1980) Rural water supply in the Mainland, Cross River State $\mathrm{pB}-15$

Todd DK (1980) Groundwater hydrology [M], 2nd edn. Wiley, New York p535

WHO (1993) Guidelines for drinking water quality. World Health Organisation, Geneva

WHO (1996) $\mathrm{pH}$ in Drinking water. Guidelines for drinking water quality, 2nd edn, vol 2. Health criterion and other supporting information. WHO, Geneva

WHO (2004) Guidelines for drinking water quality, 3rd edn. World Health Organization, Geneva

Wood WW (1996) Use and misuse of chloride mass balance method in estimating groundwater recharge. Groundwater 37(1):2-3

Wood WW, Sandford WE (1995) Chemical and isotopic methods for quantifying groundwater recharge in a regional, semi-arid environment. Groundwater 33:458-468 